\title{
Climatology of the Low-Level Jet East of the Andes as Derived from the NCEP-NCAR Reanalyses: Characteristics and Temporal Variability
}

\author{
Jose A. Marengo And Wagner R. SoARes \\ CPTEC/INPE, São Paulo, Brazil \\ Celeste Saulo and Matilde Nicolini \\ CIMA/University of Buenos Aires, Buenos Aires, Argentina
}

(Manuscript received 15 January 2003, in final form 14 January 2004)

\begin{abstract}
A climatology of the South American low-level jet east of the Andes (SALLJ) is developed using the 19502000 circulation and moisture fields from the NCEP-NCAR reanalyses and available upper-air observations made in Bolivia and Paraguay since 1998. Upper- and low-level circulation fields were derived for seasonal means and SALLJ composites during the warm and cold seasons. The Bonner criterion 1 was applied for sites in central Bolivia and downstream near northern Paraguay, to determine the spatial and temporal characteristics of the SALLJ. On the circulation characteristics, SALLJ composites during the warm season show the enhanced low-level meridional moisture transport coming from equatorial South America as well as an upper-level wave train emanating from the west Pacific propagating toward South America. The intensification of the warm season SALLJ follows the establishment of an upper-level ridge over southern Brazil and a trough over most of Argentina. The circulation anomalies at upper and lower levels suggest that the intensification of the SALLJ would lead to an intensification of the South Atlantic convergence zone (SACZ) later on and to the penetration of cold fronts with an area of enhanced convection ahead at the exit region of the SALLJ.

Regarding the time variability, the SALLJ seems to occur all year long, bringing tropical moist air masses from the Amazon into southern Brazil-northern Argentina more frequently in the warm season, and bringing tropical maritime air, which is less humid than the tropical air masses coming from the subtropical Atlantic high, more frequently during the cold season. SALLJs are detected mostly during the warm season to the north of $\sim 20^{\circ} \mathrm{S}$, while to the south the SALLJs seem to occur all year long. The diurnal cycle shows that SALLJs are more frequent and intense between 0600 and 1200 UTC for the warm season north of $20^{\circ} \mathrm{S}$, while at the region downstream the maximum is detected between 0000 and 0600 UTC during the cold season. At interannual time scales, even though there is a weak tendency for stronger and more frequent warm season SALLJ episodes in years with anomalously warm surface waters in the tropical Pacific, it cannot be affirmed with a large degree of certainty that there is a strong relationship between the occurrence of El Niño events and the number and/ or intensity of SALLJ episodes. However, the 1998 El Niño featured more frequent and intense warm season jet episodes than occurred during the 1999 La Niña, and this has been demonstrated by the reanalyses, the available Pan American Climate Studies-Sound Network (PACS-SONET) upper-air observations, and by other studies using independent datasets and regional modeling.
\end{abstract}

\section{Introduction}

The low-level jet (LLJ) represents a wind maximum situated within the lowest $1-2 \mathrm{~km}$, which sometimes exhibits a horizontal extent of subsynoptic dimensions and often has strong diurnal oscillations. The LLJ represents a relevant feature of the warm season low-level circulation and represents a poleward transport of warm and moist air concentrated in a relatively narrow region, with strong wind speeds at low levels downstream and

Corresponding author address: Dr. Jose A. Marengo, CPTEC/ INPE, Rodovia Presidente Dutra KM 40, Cachoeira Paulista, São Paulo 12630-000, Brazil.

E-mail: marengo@cptec.inpe.br to the east of mountain barriers, as documented in earlier studies for various regions of the world (Means 1952, 1954; Blackadar 1957; Bonner 1968; Stensrud 1996; Whiteman et al. 1997).

For the Americas, the first climatology of the lowlevel jet was implemented in the United States by Bonner (1968) and later updated by Whiteman et al. (1997). They identified that the LLJ occurred most frequently over the Great Plains east of the Rocky Mountains, with significant diurnal and seasonal variations: more LLJs episodes in early morning soundings than in the afternoon soundings, and more episodes in the warm August-September season as well. The South American LLJ east of the Andes (SALLJ) has been characterized as a narrow stream that channels the near-surface flow 


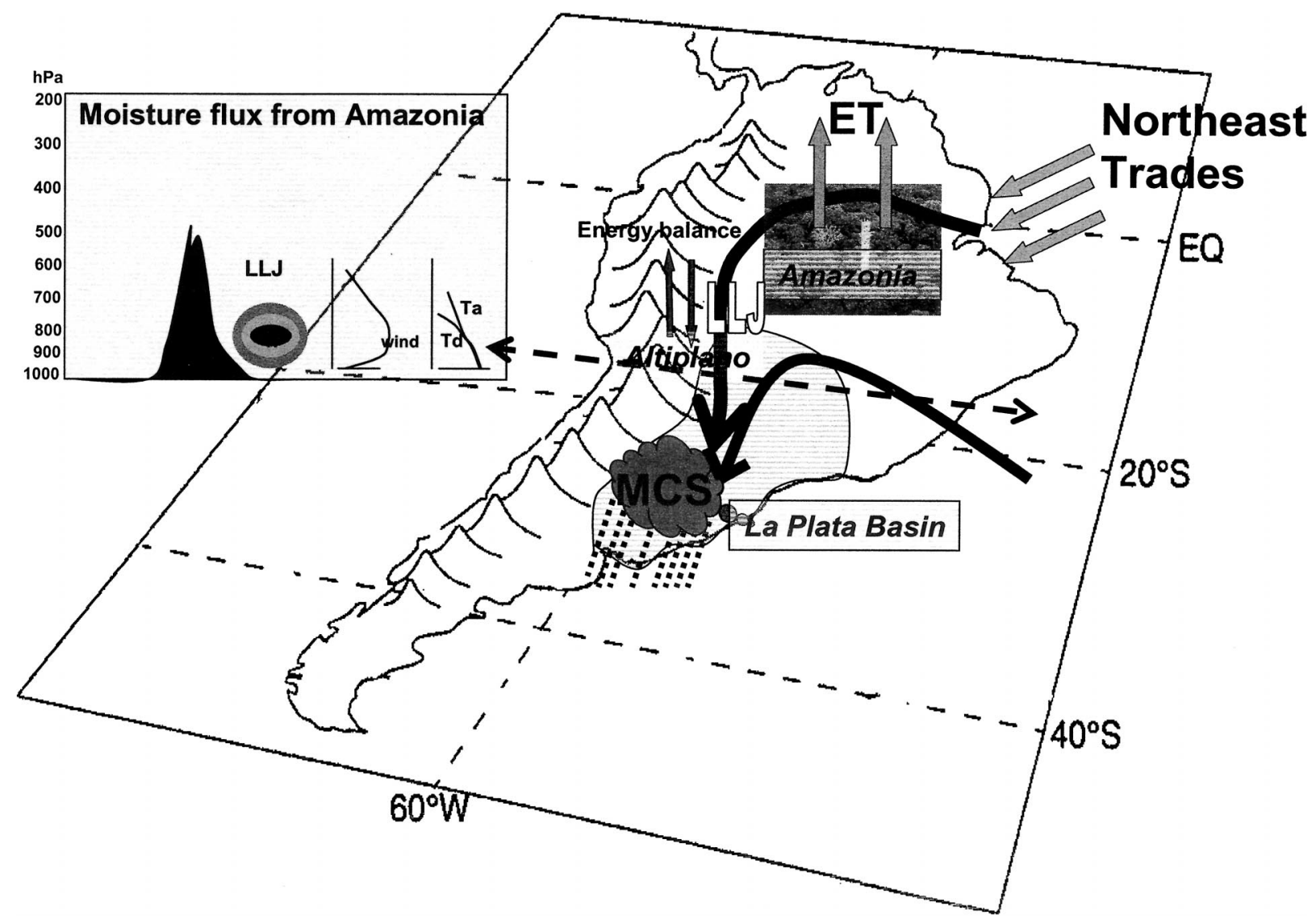

FIG. 1. Conceptual model of the SALLJ east of the Andes.

between the Tropics and midlatitudes east of the mountain range. The SALLJ is related to moisture transport from the Amazon region into the fertile lands of southern Brazil-northern Argentina and was identified in studies during the 1980s and 1990s based on a few rawinsonde observations for short-term periods or individual case studies (Virji 1981; Inzunza and Berri 1980; Berri and Inzunza 1993; Sugahara et al. 1994; Douglas et al. 1999). Recent work based on the National Centers for Environmental Prediction-National Center for Atmospheric Research (NCEP-NCAR) and European Centre for Medium-Range Weather Forecasts (ECMWF) have identified some of the circulation and moisture transport features of the low-level circulation east of the Andes, suggesting an active role for the SALLJ in the positioning and intensity of the South Atlantic convergence zone (SACZ) and the rainfall and convection at the exit region of the jet in southeastern South America (Nogués-Paegle and Mo 1997; Seluchi and Marengo 2000; Berbery and Collini 2001; Mo and Paegle 2001; Berbery and Barros 2002; Nogués-Paegle et al. 2002; Cazes-Boezio et al. 2003, and references therein). Simulations of the SALLJ using global and regional model have shown the basic low-level circulation and rainfall features detected in previous obser- vational studies (Saulo et al. 2000; Misra et al. 2000; Nicolini et al. 2002; Vernekar et al. 2003; Berbery and Collini 2000).

Figure 1 shows a conceptual model of the SALLJ as a component of the South American monsoon system. It illustrates the moisture transport coming from the Amazon-tropical North Atlantic region by the trade winds, the change in direction of the near-surface flow from northeast to southeast once it encounters the Andes, the convergence of this southeastern flow with the northwest stream coming from the subtropical Atlantic high toward the southern Brazil-northern Argentina region at the exit region of the jet, and the development of convective activity and rain at the exit region of the jet in southeastern South America over the La Plata River basin. The moisture transport is enriched by the evapotranspiration from Amazonia. The conceptual model also shows the effects of the topography in the SALLJ through dry and moist processes; the impact of the energy balance terms (sensible and latent heat) released from the Bolivian plateau while the near-surface heat low is important in terms of the impacts of transients in the SALLJ [see reviews in Paegle et al. (2001) and Noguès-Paegle et al. (2002)]. The present study concentrates on the circulation, convection, and moisture 


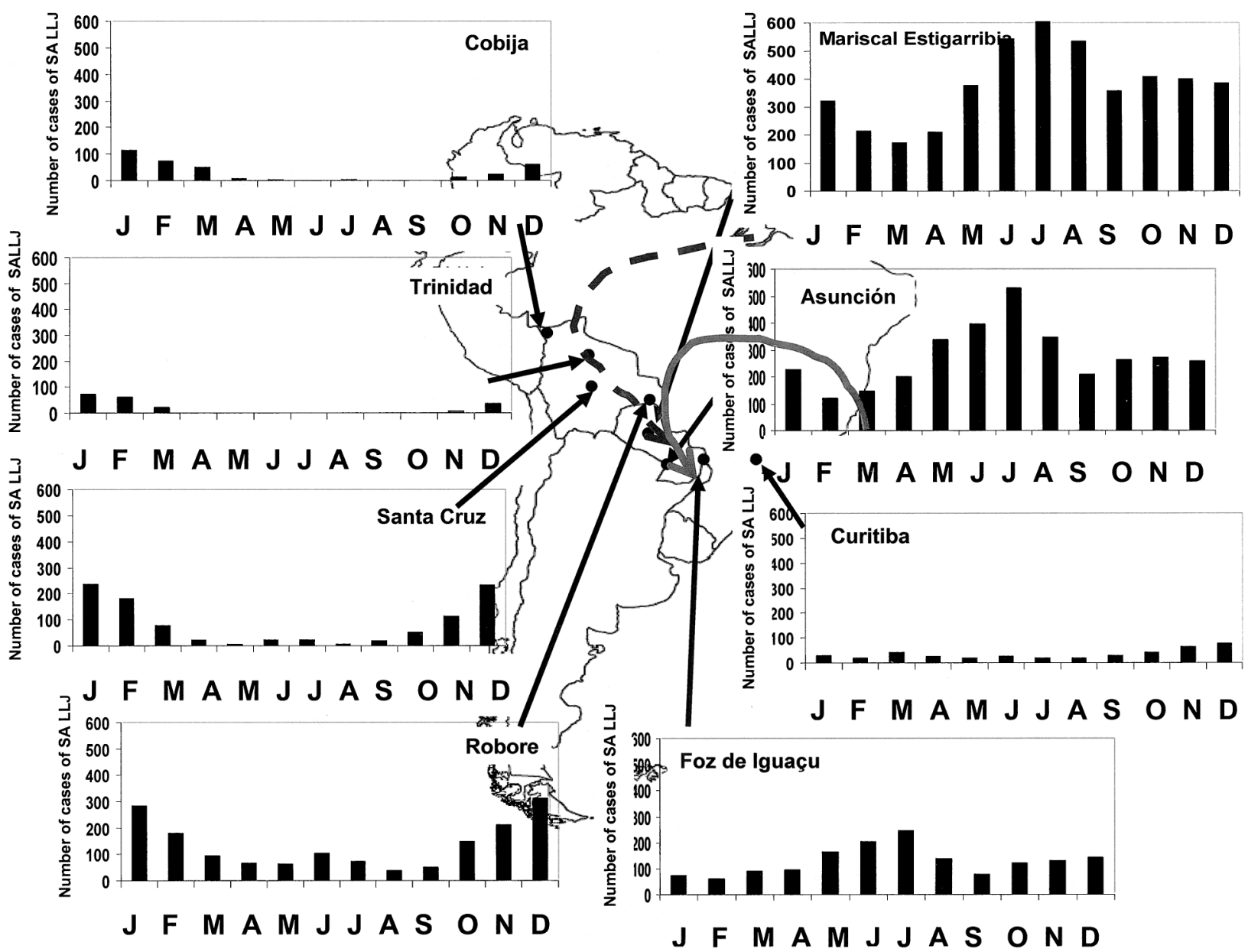

FIG. 2. Annual cycle of number of cases verifying SALLJ Bonner criterion 1. PACS-SONET and upper-air stations are shown by dots at the core and the exit region of the jet. Solid gray arrow shows the trajectory of tropical moist air coming from Amazonia, and the dotted gray arrow shows the trajectory of subtropical air from the subtropical Atlantic high. The cases were verified using the NCEP-NCAR reanalyses at the grid box closest to the stations.

transport components of the SALLJ from this conceptual model.

The SALLJ's variability in time and space is relatively poorly understood because the limited availability of the upper-air observational network in South America east of the Andes seems to be unsuitable for capturing the occurrence of the low-level jet and its horizontal extension and intensity or temporal variability. Because of the limited observational verification, the reanalyses have by necessity been taken as a reasonable approximation of the true atmospheric state over South America east of the Andes.

With the availability of upper-air observations from the Pan American Climate Studies-Sounding Network (PACS-SONET) pilot balloon network for Santa Cruz, Bolivia, since 1998 (Douglas et al. 1998, 1999, 2000), and the implementation of the Large-Scale BiosphereAtmosphere Experiment in Amazonia-Tropical Rainfall Measuring Mission (LBA-TRMM) field campaign dur- ing the austral summer of 1999 (Silva Dias et al. 2002; Marengo et al. 2002; Nieto Ferreira et al. 2003), additional rawinsonde observations in Santa Cruz have made possible the identification of some observed features of the vertical structure and diurnal variability of the SALLJ. Studies for individual cases during the austral summers of 1998 and 1999 have allowed for the detection of some important characteristics of the SALLJ. A maximum northwesterly flow below $3 \mathrm{~km}$ that can reach up to $30 \mathrm{~m} \mathrm{~s}^{-1}$ with a late afternoon maximum, was observed (based on twice-a-day observations). In comparison, Douglas et al. (1998) using regional Eta Model results showed a marked diurnal cycle with an evening maximum. Therefore, the SALLJ exhibits important observational features that still remain unexplored, among them its time variability.

The present study introduces a climatology of SALLJ episodes during the period 1950-2000 using the NCEPNCAR reanalyses. The analysis focuses on the warm 

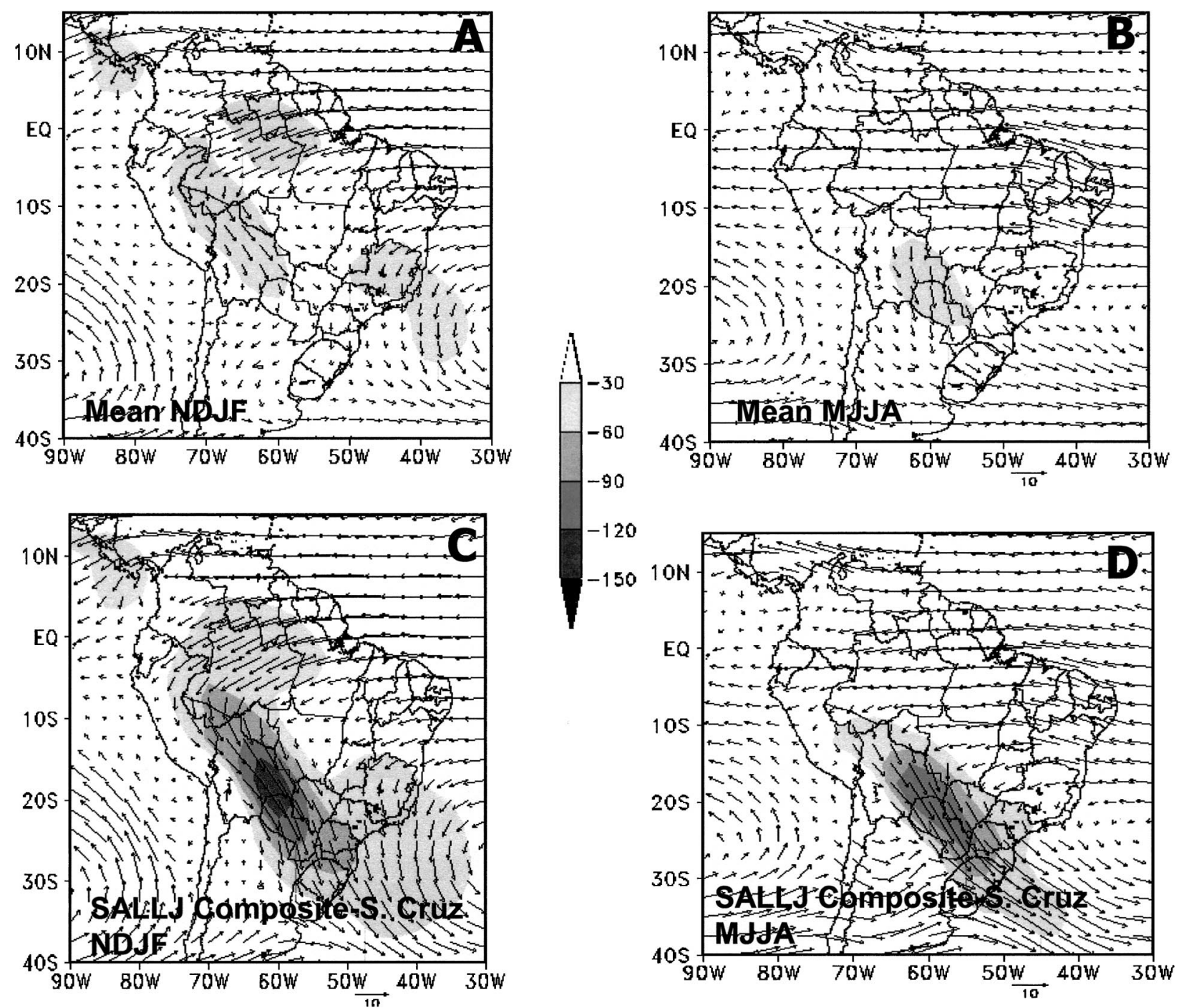

FIG. 3. Low-level $(850 \mathrm{hPa})$ wind speed $\left(\mathrm{m} \mathrm{s}^{-1}\right)$ and integrated meridional moisture convergence $\left(\mathrm{m} \mathrm{g} \mathrm{s}^{-1} \mathrm{~kg}^{-1}\right)$ for the (a) warm (NDJF) and (b) cold (MJJA) seasons for the seasonal mean for Santa Cruz. The SALLJ composite at Santa Cruz during the (c) warm and (d) cold seasons. The SALLJ composite at Mariscal Estigarribia during the (e) warm and (f) cold seasons. The mean for the SALLJ composite at both Santa Cruz and Mariscal Estigarribia during the (g) warm and (h) cold seasons.

and cold seasons for a region influence by the SALLJ (eastern Bolivia and northern Paraguay). At the moment, no long-term climatology focusing on SALLJ occurrences, for both warm and cold seasons is available. Some of the issues to be discussed in this study include a documentation of the diurnal, seasonal, and interannual variability of SALLJ activity, as well as a determination of the atmospheric circulation features that accompany SALLJ episodes. Results presented herein will be compared and discussed in relation to previous findings, with the aim of providing a comprehensive view of documented work related to SALLJ. Together with the NCEP-NCAR reanalyses, some of the few available upper-air soundings from pilot balloons from PACSSONET and rawinsondes from 1998 to 2000 in Bolivia, Paraguay, and southern Brazil are also used.

\section{Data and methodology}

\section{a. Global NCEP-NCAR reanalyses and OLR dataset}

For the analysis of circulation and moisture fields typical of the SALLJ, circulation and specific humidity fields from the surface to the $200-\mathrm{hPa}$ level at 0000 , 0600, 1200, and 1800 UTC were extracted from the NCEP-NCAR reanalyses (Kalnay et al. 1996). The resolution is set at $2.5^{\circ} \times 2.5^{\circ}$ latitude-longitude, covering 1950-2000. The analysis is centered on grid boxes along the main stream of the SALLJ in eastern Bolivia (Santa Cruz) and northern Paraguay (Mariscal Estigarribia). See Fig. 2 for locations of these sites. Previous studies (Douglas et al. 1999; Saulo et al. 2000; Marengo et al. 2002) have focused their analyses on Santa Cruz as a location representative of the core of the jet. An out- 

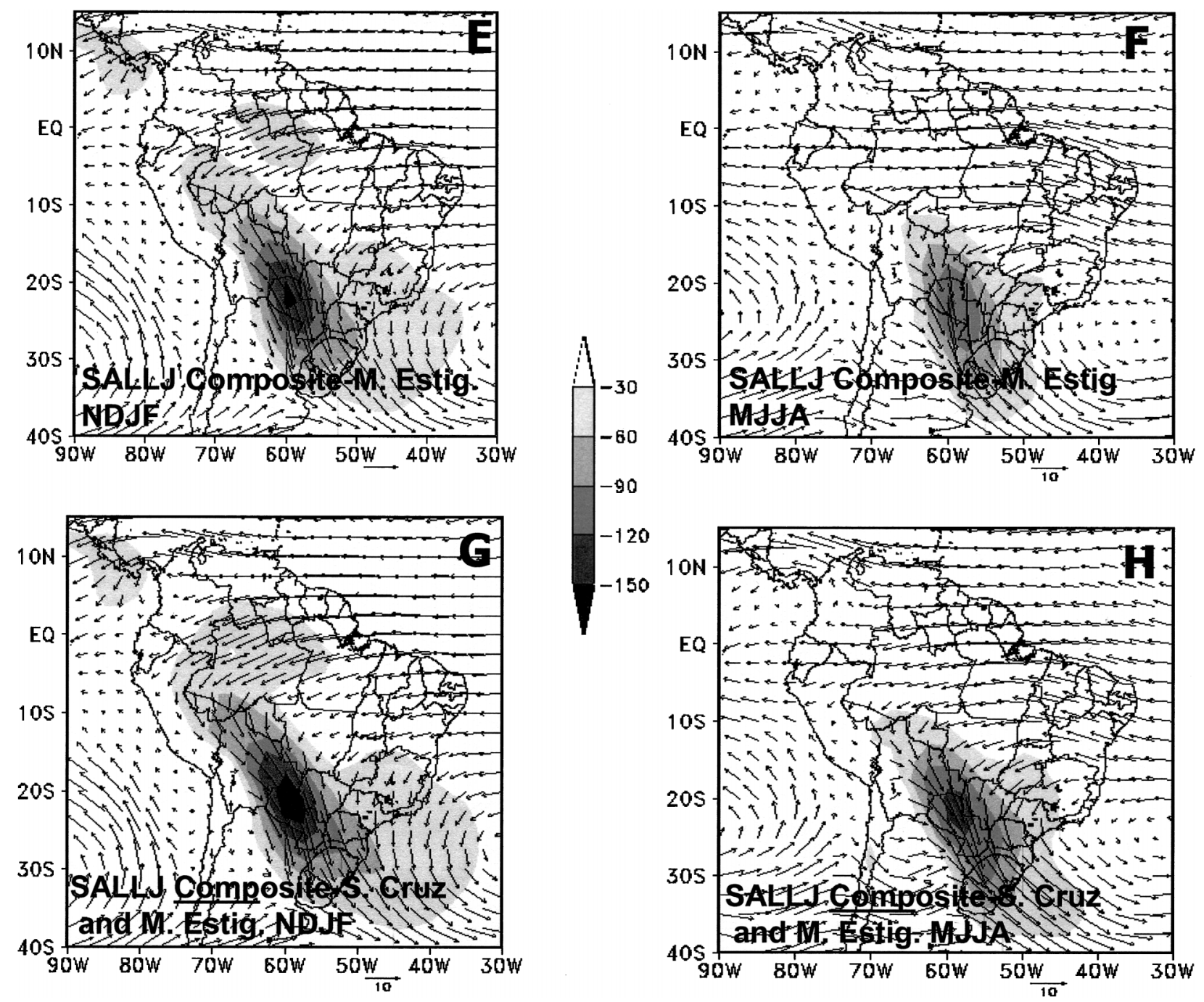

FIG. 3. (Continued)

going longwave radiation (OLR) dataset is used to analyze the convection at the exit region of the SALLJ. These data are available from 1975 to 2000 only with a horizontal resolution of $2.5^{\circ} \times 2.5^{\circ}$ latitude-longitude and were provided by NCEP.

Circulation and convection analyses are made during the spring/summer season (November-February, NDJF) and the autumn/winter (May-August, MJJA), both for the mean season and for composites of episodes with SALLJ events (the adopted definition is presented in section 2c). The level of $850 \mathrm{hPa}$ has been assumed as representative of the maximum wind level for circulation-related features of the SALLJ. Integrated moisture transport encompasses the 850-300-hPa layer.

\section{b. Upper-air observations: PACS-SONET}

The PACS-SONET is an enhanced atmospheric sounding network that has been operating since April
1997 to provide observations that will help to describe the atmospheric circulation changes associated with variations in rainfall over Mexico, Central America, and South America (Douglas et al. 1998, 1999, 2000). The network evolved to six pilot balloon stations in Bolivia (Santa Cruz, Trinidad, Roboré, Cobija, Uyuni, and La Paz), while new pilot balloon stations entered into operation in Paraguay (Mariscal Estigarribia and Asuncion) between 1999 and 2000. Pilot balloon observations were made at $\sim 0630-0700$ and $\sim 1700-1730$ local standard time (LST) each day. The difference between LST and UTC is $4 \mathrm{~h}$ for Bolivia and $3 \mathrm{~h}$ in Paraguay.

In Santa Cruz, as part of the LBA/TRMM field campaign (Silva Dias et al. 2002; Marengo et al. 2002), upper-air observations were enhanced in Santa Cruz by implementing rawinsonde observations during JanuaryApril 1999. These observations provide the opportunity to explore the characteristics and variability of the SALLJ, such as moisture transport, and examples of 
some jet case studies detected during summer and autumn 1999 are described in Marengo et al. (2002) and Marengo and Soares (2002).

\section{c. Methodology: Identification of LLJ}

The Bonner criterion 1 is applied to PACS-SONET upper-air stations and to the NCEP-NCAR reanalyses for grid boxes closest to PACS-SONET sites in Santa Cruz and Mariscal Estigarribia (Fig. 2). The sites are ideally suited for SALLJ research because they are located near the core of the stream. These are the conditions that must be met to detect a low-level jet: 1) northerly $850-\mathrm{hPa}$ winds with speeds equal or larger than $12 \mathrm{~m} \mathrm{~s}^{-1}$, 2) a vertical wind shear larger or equal than $6 \mathrm{~m} \mathrm{~s}^{-1}$ between 850 and $700 \mathrm{hPa}$, and 3) a Meridional component larger than the zonal component, and with the meridional winds from the north, in order to exclude southerly wind events. The criterion of selecting the $850-\mathrm{hPa}$ level is less restrictive than the 925$\mathrm{hPa}$ level and has been used in previous studies on SALLJ (Li and Le Treut 1999; Salio et al. 2002; Saulo et al. 2000; Marengo et al. 2002; Marengo and Soares 2002); in addition, strong jet episodes can exhibit intense near-surface winds that can be detected both at 850 and $925 \mathrm{hPa}$. Observations from the PACS-SONET sounding network from Santa Cruz during the 1998 observations (Douglas et al. 1998; Saulo et al. 2000; Marengo et al. 2002) have identified SALLJ episodes with wind speeds of up to $30 \mathrm{~m} \mathrm{~s}^{-1}$ in the northwesterly flow around $850 \mathrm{hPa}$.

Some concerns over the use of the NCEP-NCAR reanalyses for studies on spatial variability and the frequency of the SALLJ have been raised by Berbery and Barros (2002), suggesting that the global reanalyses are perhaps not the best datasets to use when examining a phenomenon like the SALLJ, which has mesoscale characteristics, and they point out the risk of using data that is affected by the global model that generates the reanalyses (regions with poor data coverage). However, some useful information regarding circulation characteristics and moisture transports can still be extracted from the reanalyses, and long-term climatologies can only be derived from datasets like this. The lack of upper-air observations precludes the selection of an adequate criterion at this stage; therefore, the Bonner criterion may be arbitrary. In any case, we have adopted it given its generalized use in previous work and for climatological purposes in the identification of low-level jets.

Once the episodes of the SALLJ are identified in the four times daily NCEP-NCAR reanalyses using Bonner criterion 1 , we then average all of these cases during 1950-2000 to implement the mean seasonal fields for the warm season (NDJF) in Santa Cruz and for the cold season (MJJA) in Mariscal Estigarribia. Then we form composites of SALLJ episodes by integrating all cases that meet Bonner criterion 1. Spatial and temporal var- iabilities for the warm and cold season circulations in South America are discussed for the seasonal mean and for the SALLJ composites. For individual SALLJ case studies, comparisons are made between wind profiles obtained from the reanalyses and those from the available upper-air observations at Santa Cruz and Mariscal Estigarribia.

\section{Low-level jet spatial and temporal variability}

In this section we describe the geographical extent, and the lower- and upper-level circulation characteristics associated with the SALLJ east of the Andes, as well as its time variability, during the warm and cold seasons. The analysis is focused on the mean circulation and for composites of SALLJ events in the two seasons. Focusing on Santa Cruz during the warm season NDJF, from the total of 24532 wind occurrences detected from 1950 to 2000, a subtotal of 764 cases exhibited a lowlevel jet, suggesting that from the total of wind occurrences during this period and season, roughly $3 \%$ featured a low-level jet.

\section{a. Geographical distribution of SALLJ wind and moisture fields during summer and winter}

Figure 2 shows the number of cases of SALLJ events along the region of the jet to the east of the Andes as derived from the NCEP-NCAR reanalyses, indicating that the SALLJ annual cycle depends on the latitude, the proximity to the Andes, and the circulation features during those seasons. In general SALLJ episodes can be detected during the entire year, as compared to the summertime-only LLJ in the U.S. Great Plains as identified in Berbery and Barros (2002).

At lower latitudes, the seasonal cycle shows that SALLJ occurrences peak during warm months, while south of Mariscal Estigarribia $\left(20^{\circ} \mathrm{S}\right)$ there are more jet episodes detected during the cold season. This is a first indication that the mechanisms organizing the low-level jets at these latitudes during both warm and cold seasons may not be the same. There may be SALLJ episodes detected during the warm season in Santa Cruz that may not show at Mariscal Estigarribia, and on a few occasions SALLJs are detected in Santa Cruz and Mariscal Estigarribia with just a few hours of difference. The fact the there are more SALLJ episodes detected during the autumn/cold seasons in Mariscal Estigarribia as compared to Santa Cruz is something that deserves special attention and will be discussed later on.

The mean low-level circulation during the warm and cold seasons (Figs. 3a,b) shows features similar to those identified in previous studies (Rao et al. 1996; Garreaud and Wallace 1998; Labraga et al. 2000; Salio et al. 2002; Berbery and Barros 2002). The mean 850-hPa circulation and vertically integrated moisture flux from Fig. 3a shows that the warm season is characterized by strong northeast trade winds near the equator, which veer to 


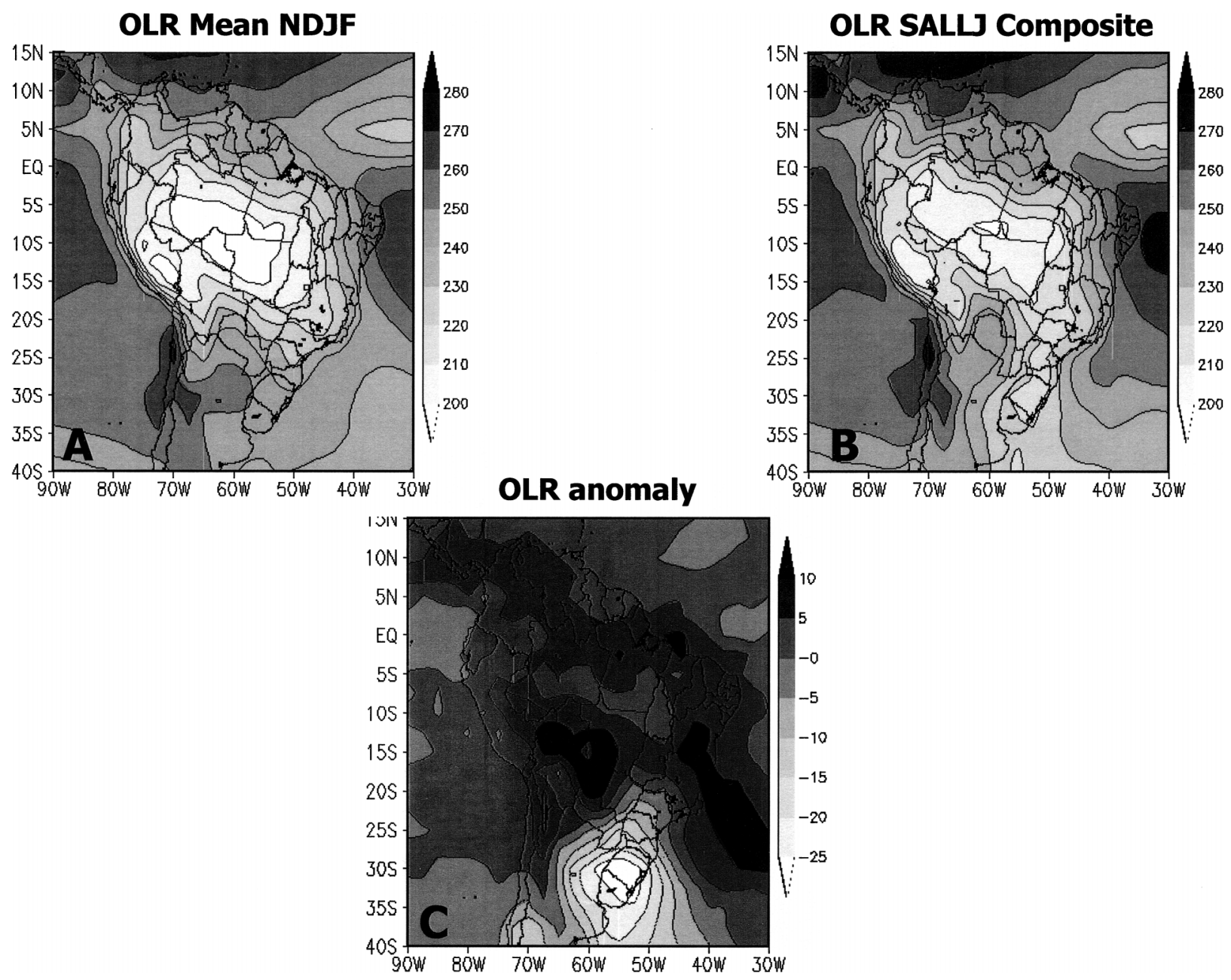

FIG. 4. OLR fields during the warm season for the 1975-2000 period: (a) mean field, (b) SALLJ composite for both Santa Cruz and Mariscal Estigarribia simultaneously, and (c) the anomaly (b) - (a). Units are in $\mathrm{W} \mathrm{m}^{-2}$.

the southwest as they approach the Andes, producing a maximum in the northwesterly flow nearby Santa Cruz $\left(\sim 17.5^{\circ} \mathrm{S}\right)$, while another maximum occurs at approximately $20^{\circ} \mathrm{S}$, associated with the subtropical Atlantic high and the Brazilian Planalto. Figure $3 \mathrm{~b}$ shows the 850-hPa circulation for the cold season, with the weakening of the northeast trades and the irruption of tropical air, while the strong northerly flow over eastern Bolivia and Paraguay is due to the intensification of synoptic eddies in the moisture fluxes, as described in previous studies (Rao et al. 1996; Labraga et al. 2000; Vera et al. 2002).

Figures $3 \mathrm{c}$ and $3 \mathrm{~d}$ show the mean low-level circulation and moisture transport fields for a SALLJ composite detected in Santa Cruz for the warm and cold seasons. The warm season SALLJ composite map shows an intensification of the circulation features of the season mean, specifically the enhanced northeast trades from the tropical North Atlantic, the low-level flow east of the Andes, and the enhanced meridional moisture transport coming from tropical South America, which is almost twice the mean of the summer season. In winter, while still enhanced, the pattern does not seem to be as efficient as it is in summer at producing precipitation with in the continent. Similar figures for SALLJ composites for Mariscal Estigarribia during the warm and cold seasons (Figs. 3e,f) show a weakening of the northeast trade winds and moisture transport and a more concentrated maximum flux, possibly associated with transient eddies as suggested by Berbery and Barros (2002) and Vera et al. (2002). Figures $3 e$ and $3 f$ show the intensification of the winds from the subtropical Atlantic high contributed to the acceleration of the SALLJ stream driving moisture directly into the La Plata basin.

The analyses of Figs. 2 and $3 \mathrm{a}-\mathrm{f}$ show that there might be SALLJ episodes detected in Mariscal Estigarribia that are not detected in Santa Cruz and vice versa. A strong SALLJ should in principle be detected in both Santa Cruz and Mariscal Estigarribia, and it is during the austral summer when strong SALLJ events are detected in both seasons. Therefore, Figs. $3 \mathrm{~g}$ and $3 \mathrm{~h}$ show the circulation fields for a SALLJ composite of episodes 

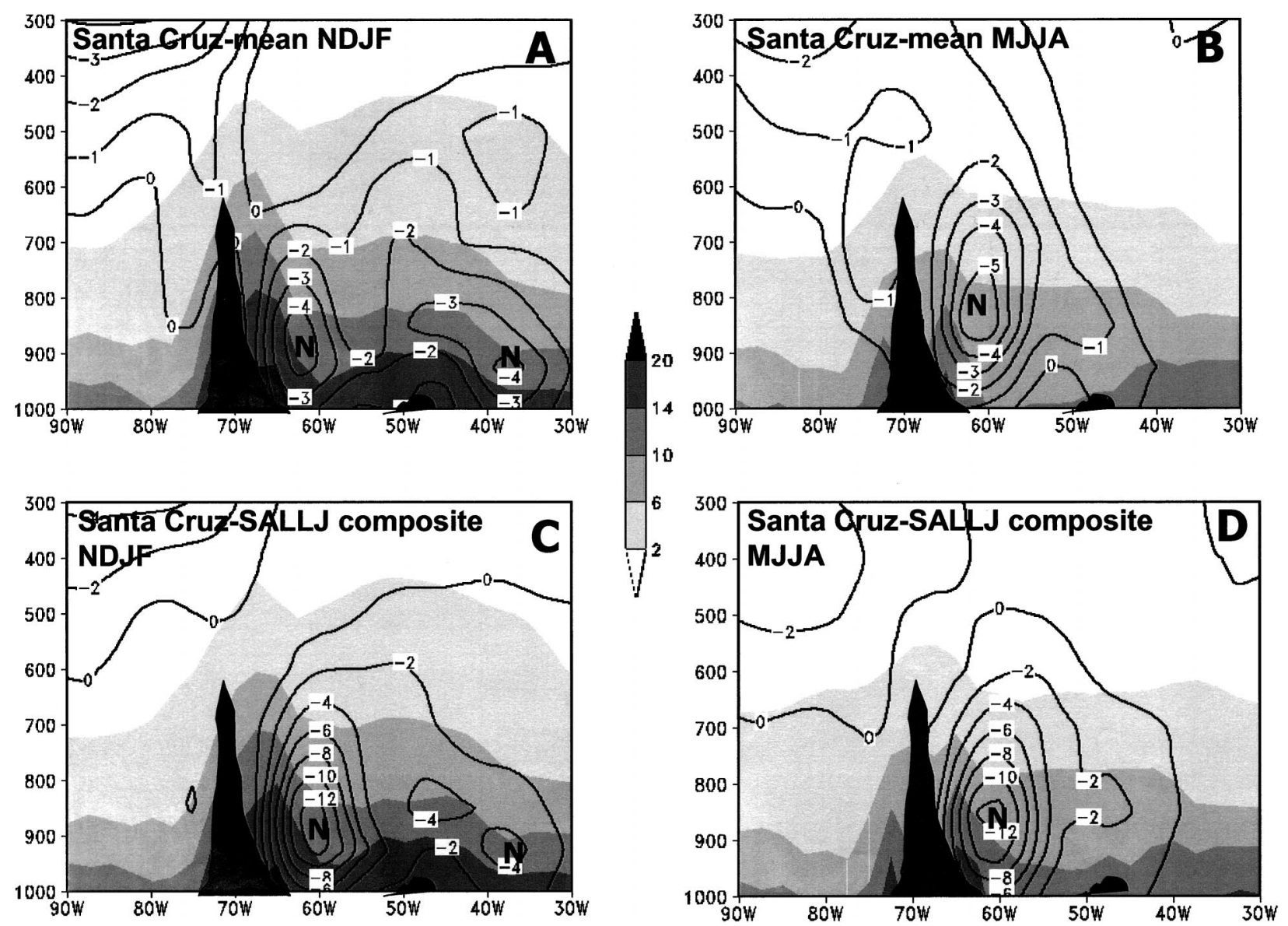

FIG. 5. Cross sections of meridional wind speed $\left(\mathrm{m} \mathrm{s}^{-1}\right)$ and specific humidity $\left(\mathrm{g} \mathrm{kg}^{-1}\right)$ along $17.5^{\circ} \mathrm{S}$ (near Santa Cruz) and $23.5^{\circ} \mathrm{S}$ (near Mariscal Estigarribia) for (a) the warm (NDJF) and (b) the cold (MJJA) seasons for the seasonal mean for Santa Cruz. The SALLJ composite at Santa Cruz during the (c) warm and (d) cold seasons. The seasonal mean for Mariscal Estigarribia for the (e) warm and (f) cold seasons. The mean for the SALLJ composite at Mariscal Estigarribia during the (g) warm and $(\mathrm{h})$ cold seasons.

for both Santa Cruz and Mariscal Estigarribia for the warm and cold seasons. The warm season SALLJ composite (Fig. 3g) resembles the circulation features of the strong Chaco LLJs identified by Salio et al. (2002) using the ECMWF reanalyses during austral summer: strong surface winds that meet Bonner criterion 1 and that can reach $25^{\circ} \mathrm{S}$ with more than $12 \mathrm{~m} \mathrm{~s}^{-1}$. The warm season SALLJ composite from Fig. $3 \mathrm{~g}$ is characterized by an important low-level flux of moisture that is stronger than the season mean (Fig. 3a) and than the SALLJ composite for Santa Cruz (Fig. 3c). Figures 3g and 3h are in close agreement with Fig. 11 from Salio et al. (2002) for the Chaco LLJ ensembles, and this provides grounds for an assumption that Figs. $3 \mathrm{~g}$ and $3 \mathrm{~h}$ can be representative of stronger SALLJs during the warm season, meeting Bonner criterion 1.

The presence of SALLJ episodes represented by the maximum low-level flow near the Andes is clear in both warm and cold seasons. In Santa Cruz, during the warm season the main cause is the incursion of warm and humid air from tropical South America, while in winter the SALLJ events are liked to the intensification of the subtropical Atlantic high and to the impact of synoptic perturbations as shown by Vera et al. (2002), which can reach this latitude during winter and which in turn are more frequent during the cold season than in the warm season. In the next section, there will be indicators that the air masses are different for the SALLJ episodes during these two contrasting seasons.

In relation to the convective activity, Figs. $4 \mathrm{a}-\mathrm{c}$ show the OLR fields (1975-2000) for the mean warm season, for the strong SALLJ composite, and the difference field between the composite and season mean. Perhaps, the most revealing information can be extracted from the anomaly field (Fig. 4c). The SALLJ OLR warm season composite shows increased convective activity over southeastern South America at the exit region of the jet, as well as weaker convection in central Brazil and along the SACZ. Nogués-Paegle and Mo (1997), Salio et al. (2002), and Nieto Ferreira et al. (2003), using different methods, have also identified that strong SALLJs are linked to a weak SACZ, suggesting that our warm season SALLJ composites are consistent enough to depict 

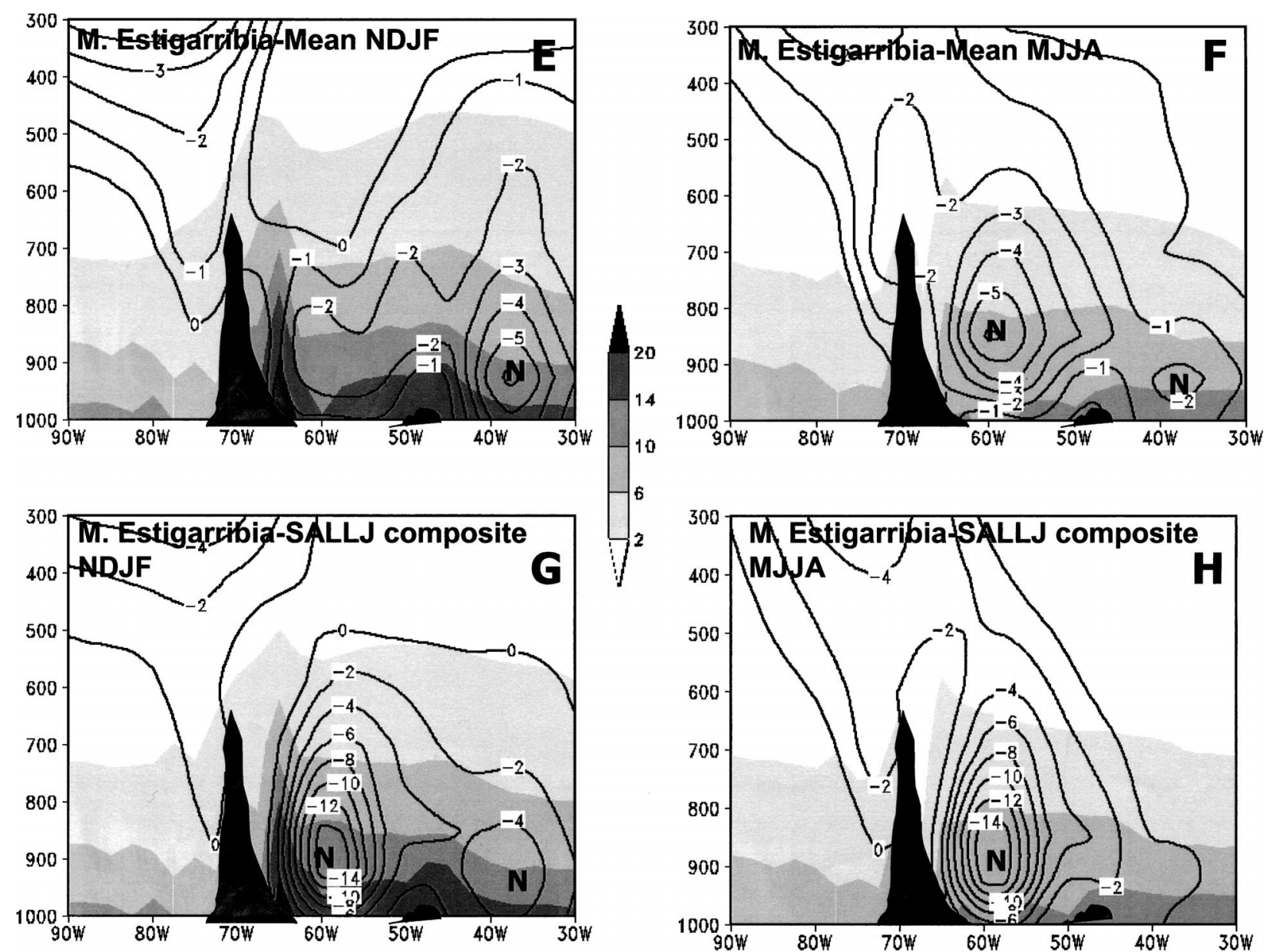

FIG. 5. (Continued)

circulation and convection features associated with the low-level jet east of the Andes.

Cross sections of meridional wind and specific humidity along $17.5^{\circ}$ (Santa Cruz) and $23^{\circ} \mathrm{S}$ (Mariscal Estigarribia) are shown in Fig. 5, for the mean warm and cold seasons, and for SALLJ composites. At Santa Cruz (Figs. 5a,b,e,f) the warm season mean shows the northerly flow around $62^{\circ} \mathrm{W}$ (Fig. 5a), with the maximum speed $\left(\sim 4 \mathrm{~m} \mathrm{~s}^{-1}\right)$ at $900 \mathrm{hPa}$, as well as another shallow maximum at lower levels and approximately at $38^{\circ} \mathrm{W}$. The cold season mean (Fig. 5b) is characterized by stronger northerly flow with a maximum a bit higher (around $800 \mathrm{hPa}$ ) and relatively less moisture content as compared to the warm season mean circulation. The composite of the SALLJ during the warm season (Fig. 5e) shows northerly flow reaching $12 \mathrm{~m} \mathrm{~s}^{-1}$, with a maximum between 850 and $900 \mathrm{hPa}$ and extending up to $50^{\circ} \mathrm{W}$ near the Brazilian Planalto with a secondary maximum over the adjacent oceans, west of $40^{\circ} \mathrm{W}$, while the cold season composite shows similar intensities even though it is narrower than the warm season composite (Fig. 5f).

The mean warm season pattern at the latitude of Mar- iscal Estigarribia (Fig. 5c) shows no SALLJ-like feature to the east of the Andes, and a northerly flow east of $40^{\circ} \mathrm{W}$ can be associated with an active SACZ over this area. During the mean cold season (Fig. 5d), a northerly flow is found to be located around $60^{\circ} \mathrm{W}$ and $850 \mathrm{hPa}$, with speed of $\sim 6 \mathrm{~m} \mathrm{~s}^{-1}$ and exhibiting lower moisture content as compared to Santa Cruz. For the composites with SALLJ at Mariscal Estigarribia during the warm season (Fig. 5g), the episodes detected at this site exhibit the same behavior as the SALLJ composite in Santa Cruz (Fig. 5e), with the difference being that Santa Cruz shows more SALLJ events in the warm season while Mariscal Estigarribia shows more SALLJ events during the cold season (Fig. 2). The SALLJ composite for the warm season (Fig. 5g) shows a strong northerly flow around $58^{\circ} \mathrm{W}$ and with a maximum speed $\sim 15-16 \mathrm{~m}$ $\mathrm{s}^{-1}$, and it is shallower $(\sim 900 \mathrm{hPa})$ than the composite in Santa Cruz. The cold season SALLJ composite (Fig. $5 \mathrm{~h})$ exhibits stronger northerly winds and relatively less moisture content as compared to a similar composite for summer (Fig. 5g).

The cross sections of mean warm and cold season meridional winds and moisture content in Santa Cruz 

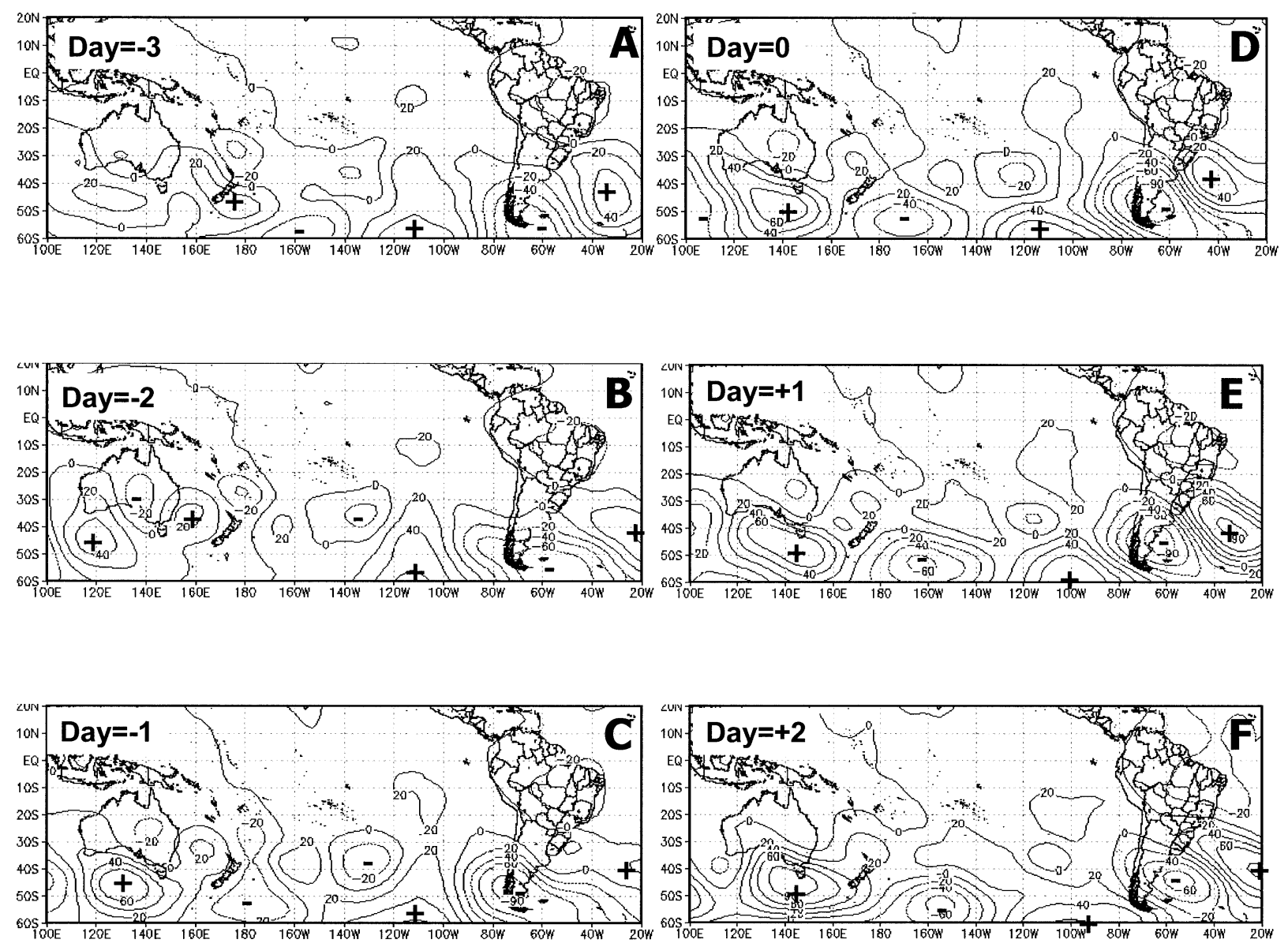

FIG. 6. Upper-level NCEP-NCAR reanalysis 200-hPa geopotential height anomalies for SALLJ composite during the warm season (NDJF), for episodes detected at grid boxes closest to Santa Cruz and Mariscal Estigarribia simultaneously. Sequence of panels shows the circulation features before, during, and after the day when the SALLJ reaches its maximum intensity at day 0. Plus and minus signs denote anticyclonic and cyclonic anomalies, respectively.

and Mariscal Estigarribia (Fig. 5), respectively, resemble Figs. 9c and 9d of Berbery and Barros (2002). In fact, their figures show intense southward moisture flux within the structure of the low-level jet east of the Andes. Figure 5 shows more details than are seen in Berbery and Barros (2002), indicating higher moisture content of the warm season SALLJ as compared to relatively lower moisture content present in the cold season SALLJ.

Based on the circulation features from Figs. 2-5 and the conceptual model in Fig. 1, stronger SALLJ episodes during the warm season that are characterized by northerly transport of tropical moist air from the tropical North Atlantic-Amazon regions toward the subtropical regions of Brazil-northern Argentina, and that are capable of producing stronger convective activity and rainfall at this region are observed. More frequent and stronger SALLJ episodes were identified during the warm season in Santa Cruz and during the cold season in Mariscal Estigarribia. The difference is that the stronger jets in Mariscal Estigarribia bring less humid air as compared to the moister air carried out by the northerly flow during the warm season in Santa Cruz. The strength of the SALLJ flow at Santa Cruz during the warm season is mostly contributed by the equatorial source and enhanced by synoptic perturbations as are analyzed in section $3 \mathrm{~b}$. In the cold season, the signal of the SALLJ in Mariscal Estigarribia is more related to synoptic midlatitude perturbations rather than tropical influences.

\section{b. Upper-and low-level circulation features associated to the presence of intense SALLJ}

Figures 6 and 7 show an evolution of upper- and lowlevel circulation features for SALLJ composites during the warm season from day -3 to day +2 , assuming day 0 as the date where the SALLJ reaches it maximum intensity in Santa Cruz. At higher levels (Figs. 6a-g), the SALLJ circulation composites suggest a wave train that emanates from the midlatitude western Pacific and then propagates toward South America, turning equatorward as it crosses the Andes around the southern tip of South America. An anomalous upper-level trough (ridge) over southern South America (southern Brazil) 

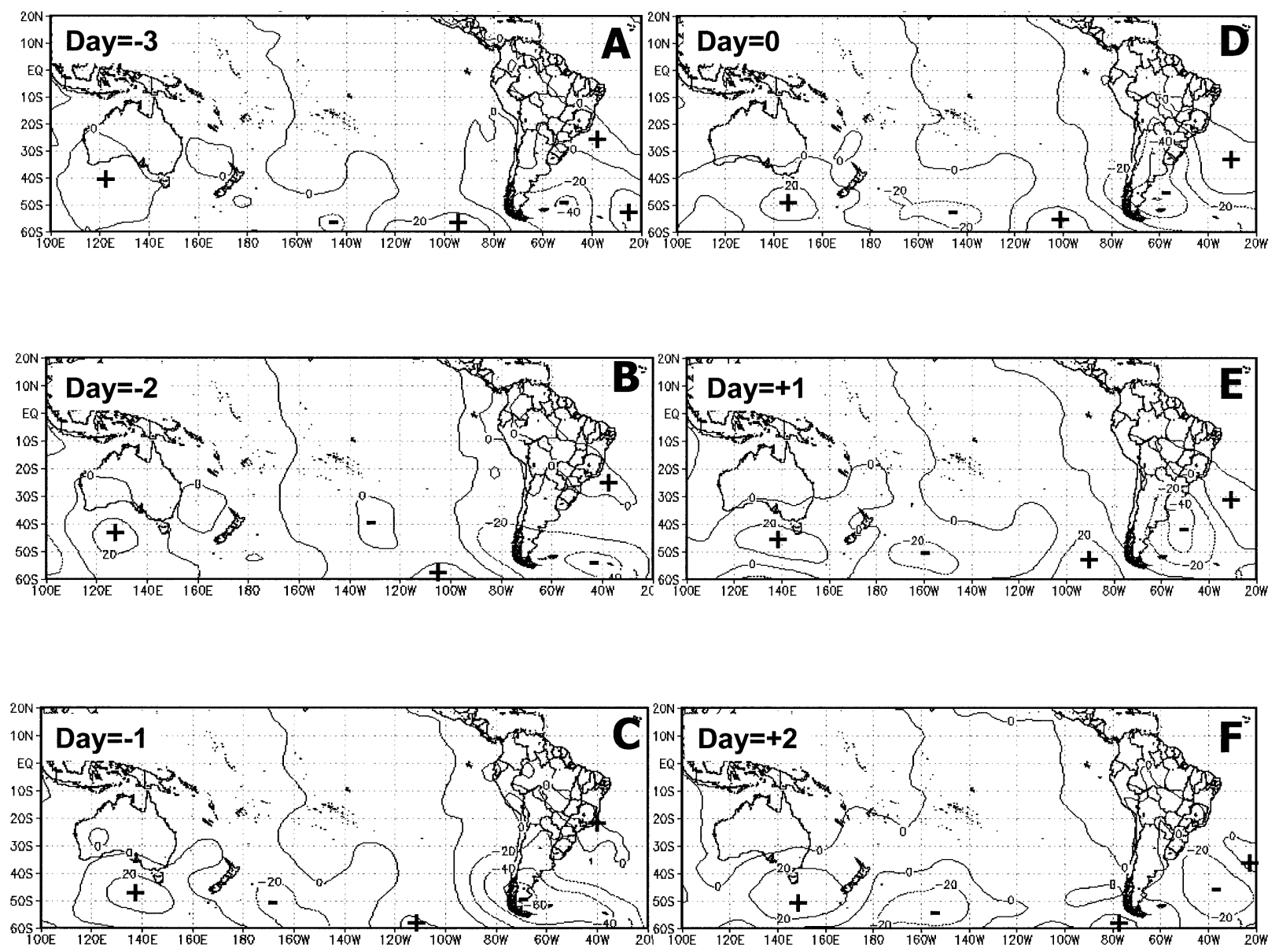

FIG. 7. Low-level NCEP-NCAR reanalysis $850-\mathrm{hPa}$ geopotential height anomalies for the SALLJ composite during the warm season (NDJF), for episodes detected at grid boxes closest to Santa Cruz and Mariscal Estigarribia simultaneously. Sequence of panels shows the circulation features before, during, and after the day when the SALLJ reaches its maximum intensity at day 0. Plus and minus signs denote anticyclonic and cyclonic anomalies, respectively.

is embedded in a wave pattern. This trough is intensified 1 day before the SALLJ reaches its largest intensity to the east of the Andes and then dissipates 3 days after the SALLJ weakens.

The wave pattern in Figs. $6 \mathrm{a}$ and $6 \mathrm{~b}$ shows some resemblance to that related to the SACZ activity from Liebmann et al. (1999). However, there is an out-ofphase relationship between the SALLJ composites in Figs. 6a-g and the SACZ composites in Fig. 4 of Liebmann et al. (1999), where the cyclonic anomalies in the SALLJ contrast with the anticyclonic anomalies in the SACZ composites for the same regions in South America. This suggests that moisture transport and possibly rainfall downstream of the jet or in the SACZ show a contrasting pattern, with enhanced convection and rainfall due to an enhanced SALLJ consistent with periods of weak SACZ and vice versa and consistent with Fig. 4c. The pattern identified in Fig. 6 for the warm season SALLJ composite also resembles the upper-air wave patterns identified in previous studies of subseasonal variability of convection and low-level circulation in
South America. These studies used different approaches such as principle component or regression analysis associated with the variability of austral summertime lowlevel circulation, convection, and rainfall (Nogués-Paegle and Mo 1997; Mo and Paegle 2001; Salio et al. 2002; Herdies et al. 2002; Cazes-Boezio et al. 2003; Liebmann et al. 2004).

At near-surface levels (Figs. 7c,d), the $850-\mathrm{hPa}$ SALLJ circulation composites show a baroclinic structure, with cyclonic anomalies over southern South America that start to intensify 2 days before the intense SALLJ east of the Andes. On day -1 the anomalous low-level northwesterly flow that extends from northern Bolivia to southern Brazil and Uruguay starts to intensify and by days 0 and day +1 this flux from the north is intensified, to be dissipated later (day +3$)$. The intensification of a low-level trough extending from southern Argentina toward the northwest along the eastern side of the Andes is an indicator of the intensified SALLJ. This figure provides further evidence that the pattern over Mariscal Estigarribia is more strongly in- 
Cobija - NDJF

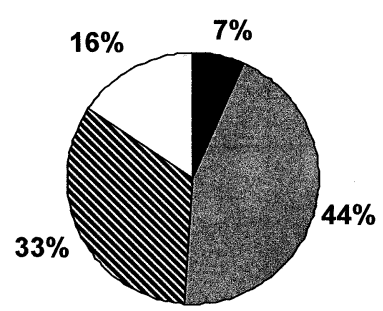

$\square 00 Z \square 06 Z$ @ $12 Z \square 18 Z$

Cobija - MJJA

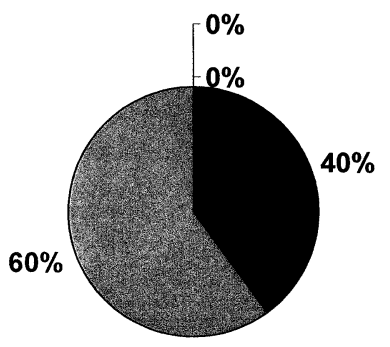

$00 z$ 뭉 $06 z \square 12 Z \square 18 Z$
Santa Cruz - NDJF

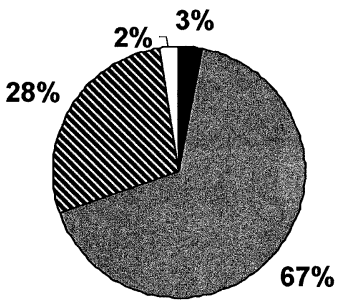

$00 Z$ 圆 $06 Z \$ 12 Z \square 18 Z$

Santa Cruz - MJJA

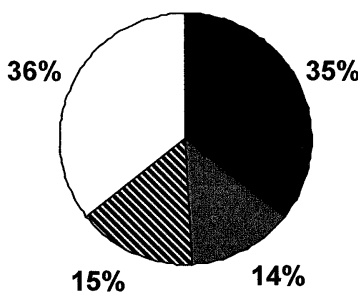

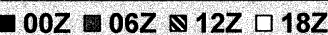

Mariscal Estigarribia - NDJF Foz do Iguaçu - NDJF
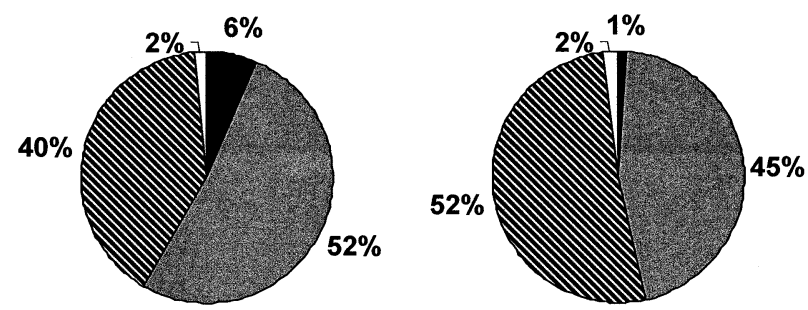

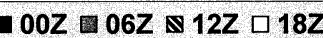

$00 Z$ 圆 $06 z$ \& $12 Z \square 18 Z$

Mariscal Estigarribia-MJJA

Foz do Iguaçu - MJJA
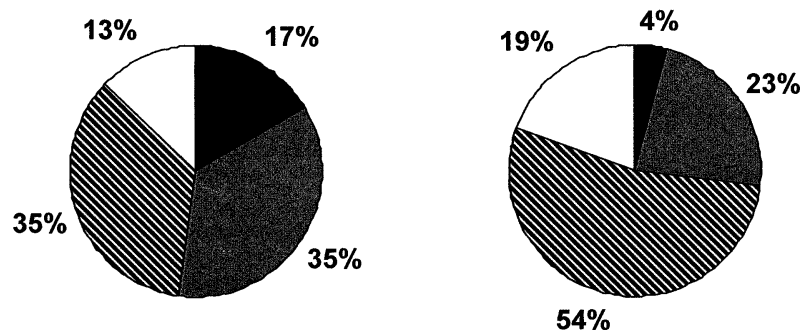

$00 Z=06 Z \otimes 12 Z \square 18 Z$
$00 Z$ 06Z $₫ 12 Z \square 18 Z$

FIG. 8. Mean number of cases verifying the SALLJ at the four synoptic times (0000, 0600, 1200, and 1800 UTC) for the SALLJ composite during the warm season (NDJF) and cold season (MMJA), for stations along the main stream of the jet: Cobija, Santa Cruz, Mariscal Estigarribia, and Foz de Iguaçu. See Fig. 2 for locations of stations.

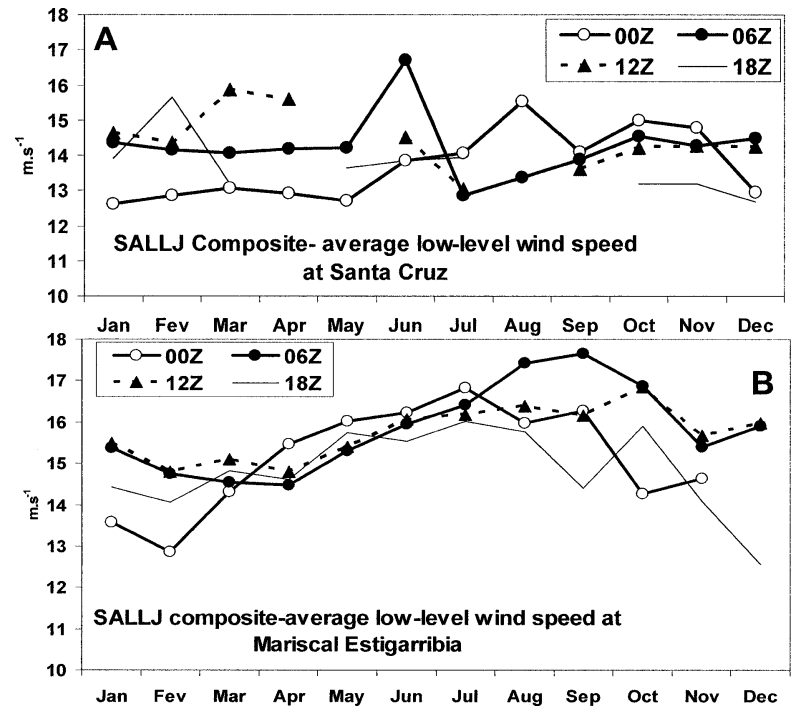

FIG. 9. Monthly low-level wind speed for SALLJ composites at the four synoptic times $(0000,0600,1200$, and 1800 UTC) in (a) Santa Cruz and (b) Mariscal Estigarribia. Units are $\mathrm{m} \mathrm{s}^{-1}$. fluenced by synoptic-transient activity that the area around Santa Cruz.

\section{c. Time variability}

In this section, we analyze the variability in time of the frequency and intensity of the SALLJ, focusing on the mean warm and cold seasons, and on SALLJ composites during these two seasons.

\section{1) Annual and diurnal cycle}

Considering both the occurrences and intensity of the SALLJ and in the context of the SALLJ annual cycle in Fig. 2, Figs. 8 and 9 have been constructed to analyze the preferred diurnal cycle of SALLJs. In Santa Cruz (Fig. 9a), 67\% of the SALLJ cases were detected at 0600 UTC during the warm season, and at the other sites along the SALLJ stream (Cobija and Mariscal Estigarribia; Figs. 8a,c) the more frequent events during summertime are also detected at 0600 UTC, and at 1200 UTC in Foz de Iguaçu (Fig. 8d). During the cold season, the more frequent SALLJ events (35\%-54\%) are de- 


\section{Santa Cruz- NDJF}
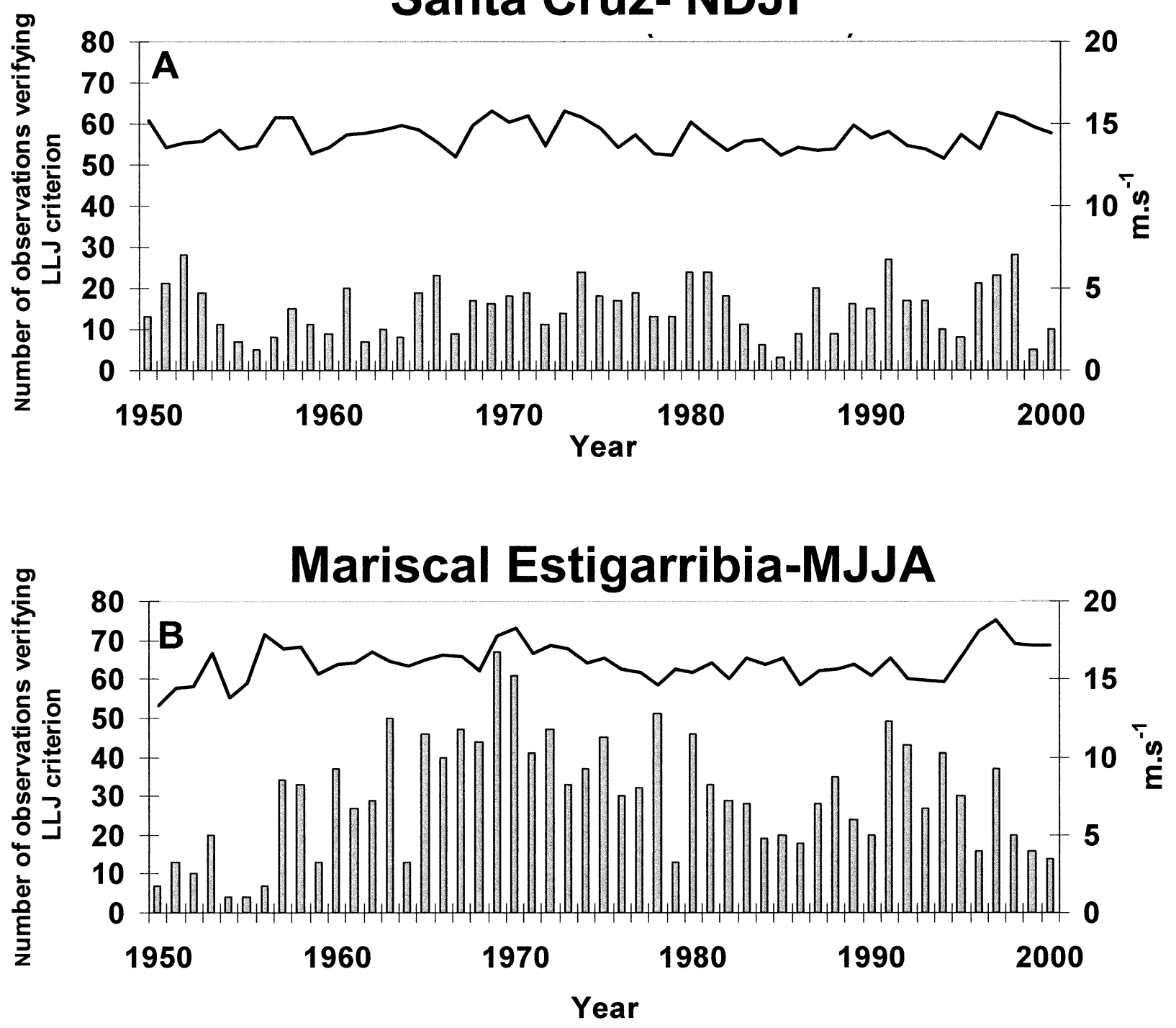

FIG. 10. Interannual variability of the number of cases verifying the SALLJ criterion and the mean wind speed of an SALLJ composite during (a) warm season NDJF in Santa Cruz and (b) cold season MJJA in Mariscal Estigarribia. At Santa Cruz, the wind represents the average of 0600 and 1200 UTC (time of the maximum intensity), while at Mariscal Estigarribia the average is for 0000 and 0600 UTC (time of the maximum intensity). Frequency of SALLJ occurrences is shown along the vertical coordinate on the left, and the wind speed is shown at the vertical coordinate on the right. See Fig. 2 for locations of stations.

tected at $1200 \mathrm{UTC}$ (followed by $0600 \mathrm{UTC}$ ) at Mariscal Estigarribia and Foz de Iguaçu (Figs. 8g,h), at 0600 UTC followed by 0000 UTC in Cobija, and at 0000 UTC and at 1800 UTC Santa Cruz (Figs. 8e,f). Results at Santa Cruz are consistent with the diurnal oscillation documented by Salio et al. (2002) during the warm season. Figures 9a and 9b show that in Santa Cruz, LLJ winds show a maximum of $14 \mathrm{~m} \mathrm{~s}^{-1}$ between 0600 and 1200 UTC during the warm season, with the stronger winds during the cold season occurring between 0000 and 0600 UTC. In Mariscal Estigarribia, the winds are in general stronger than those in Santa Cruz, especially during the cold season. As in Santa Cruz, the maximum near-surface winds are detected at 1200 and 0600 UTC during the warm and cold seasons, respectively.

The larger variability for the preferred hour of SALLJ occurrences detected in winter (Fig. 10c) may be another indication that during this season synoptic-transient activity (which in turn is not characterized by a clear diurnal cycle) is the main forcing mechanism for SALLJ formation. On the other hand, the preferred nocturnal or very early morning SALLJ occurrence (between 0600 and 1200 UTC) over all the selected stations in summer suggests the influence of boundary layer mechanisms in organizing this pattern during this season. As suggested in the literature, there is not an equivalent number 


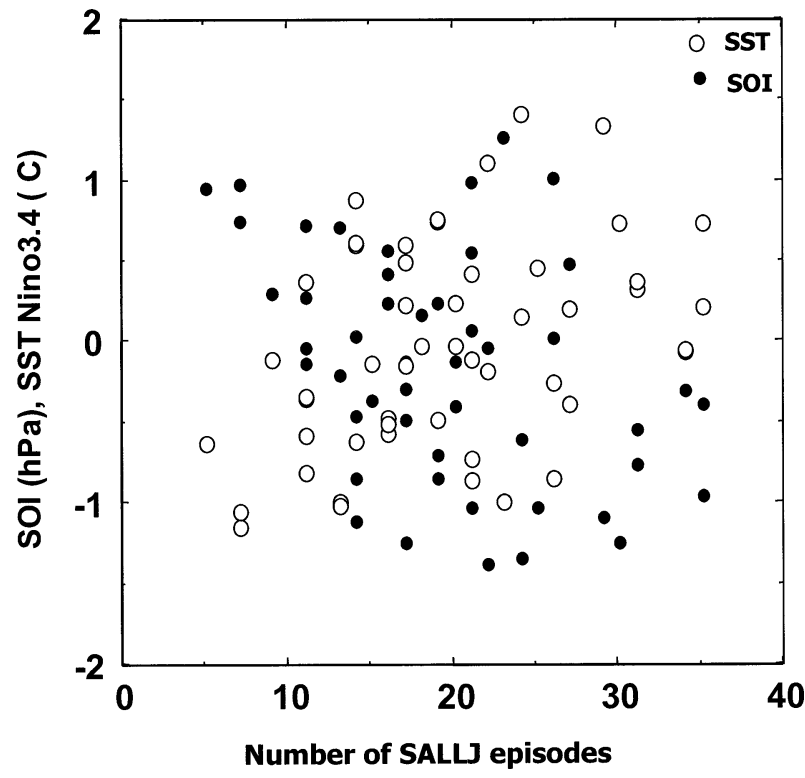

FIG. 11. Scatter diagram of annual Southern Oscillation index (SOI), SST anomalies in Niño-3.4 region, and the number of cases of SALLJ at Santa Cruz during NDJF. Filled circles represent the SOI and empty open circles represent the SST.

of wintertime low-level jets in the U.S. Great Plains (Berbery and Barros 2002).

Previous observational studies in Santa Cruz during April 1999 (Douglas et al. 1999; Marengo et al. 2002) have shown a maximum wind speed at $850 \mathrm{hPa}$ between 0600 and 1200 UTC and a minimum around 1800 UTC. However, the observations were made only twice a day, and there is still some uncertainty over whether this sampling time would catch the real daily peaks or not. The analysis of wind profiles during the summer/autumn of 1998 in Santa Cruz (Douglas et al. 1998) identifies a deep and late afternoon (rather than shallow and early morning) wind maximum at Santa Cruz, which is in general agreement with studies based on $1 \mathrm{yr}$ of sounding data performed by Inzunza and Berri (1980) in Salta, Argentina $\left(25^{\circ} \mathrm{S}\right.$, just east of the Andes). However, these findings were based on twice-a-day observations of rawinsondes or pilot balloons and can hardly resolve the diurnal cycle of the SALLJ. In comparison, the diurnal cycle of the U.S. Great Plains LLJ was studied with a network of rawinsondes with higher resolution in space and time, showing maximum speeds at early morning (0200 LST) (Anderson and Arrit 2001).

\section{2) INTERANNUAL VARIABILITY}

Time series of the frequency and intensity of SALLJ episodes during 1950-2000 are shown in Figs. 10a and $10 \mathrm{~b}$ for Santa Cruz during the warm season, and for Mariscal Estigarribia during the cold season, as derived from the NCEP-NCAR reanalyses. Figure 10 does not suggest a clear signal between the occurrence of El Niño or La Niña and the number and the intensity of SALLJS at both sites. During the period with available PACSSONET pilot balloons in Santa Cruz, the number of SALLJ events during the strong 1998 El Niño was 29, and the La Niña event of 1999 featured only 7 events. The intensity of the winds based on the average for the time with the maximum wind speed from the reanalyses (0600-1200 UTC in Fig. 10b) shows that the strongest events were observed during 1997-98 while the episodes during the middle 1980s and early 1990s were relatively weaker.

Few studies using the PACS-SONET, reanalyses, and regional modeling have suggested enhanced SALLJ activity during 1998 as compared to 1999 (Douglas et al. 1999; Misra et al. 2000; Saulo et al. 2000; Vernekar et al. 2003; Marengo et al. 2002; Lau and Zhou 2003) exhibits substantial interannual variability. Both reanalyses and observations suggest fewer episodes of SALLJs in 1999 as compared to 1998, but the lack of observations during other El Niño events does not allow for a general conclusion between the presence of El Niño and a more active SALLJ season. In this regard, the scatter diagram in Fig. 11 shows the associations between the annual Southern Oscillation index and SST anomalies for the Niño-3.4 region $\left(5^{\circ} \mathrm{S}-5^{\circ} \mathrm{N}, 170^{\circ}-\right.$ $120^{\circ} \mathrm{W}$ ) and the number of SALLJs during the warm season NDJF in Santa Cruz for 1950-2000. The diagram shows a somewhat moderate influence of El Niño occurrences on the warm season SALLJ activity, and the correlation coefficient $(0.46$, significant at the $95 \%$ level) suggests that approximately $20 \%$ [or $R^{2}$ as explained in von Storch and Zwiers (1999, p. 154)] of the variance in the number of SALLJ events can be explained by the warming of the tropical Pacific due to El Niño.

In order to identify the potential role of the SST of the tropical oceans, and the SALLJ activity, Fig. 12 shows regression maps of the number of warm season SALLJs detected in Santa Cruz and SST anomalies during spring and early summer for the 1950-2000 period. The maps show positive and statistically significant correlations between the SALLJ frequency and SST anomalies in the Pacific Ocean, while the correlations in the tropical Atlantic are very weak. However the correlations barely surpass 0.4 , implying that less than $20 \%$ of the SALLJ variance can be explained by the SST anomalies in the tropical Pacific. The size of the correlations indicates a more important role for tropical Pacific SST anomalies during September (Fig. 12c) as compared to November (Fig. 12a) or even during January or February (not shown).

The physical explanation of this is that warm SST anomalies in the tropical Pacific excited an anomalous east-west overturning with sinking motion and low-level easterlies in northern Brazil. These easterlies turn southwestward when encountering the Andes, enhancing the SALLJ activity and increased rainfall was detected over southern subtropical South America, while the SACZ was weak. On the other hand, cold waters in 
A-Correlations SALLJ NDJF Santa Cruz-November SST

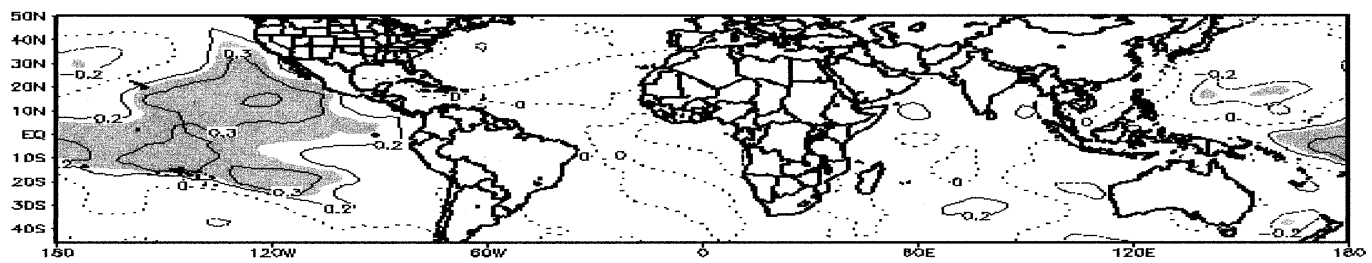

B-Correlations SALLJ NDJF Santa Cruz-October SST

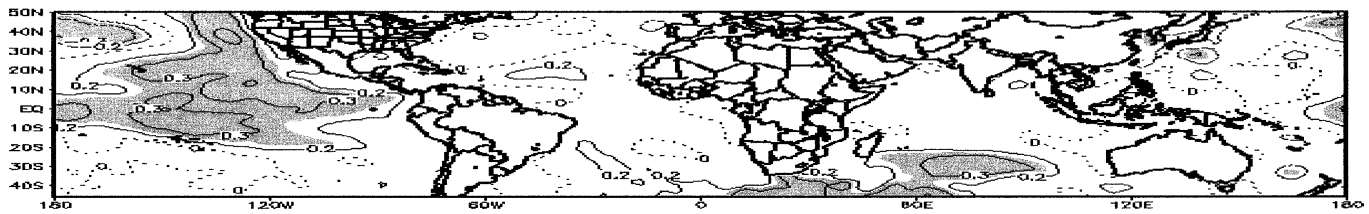

\section{C-Correlations SALLJ NDJF Santa Cruz-September SST}

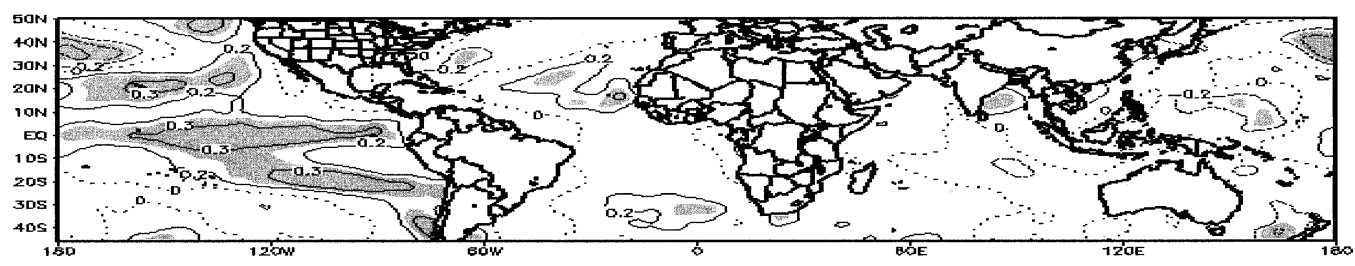

FIG. 12. Correlation coefficients between tropical SSTs and the frequency of SALLJ events detected in Santa Cruz during NDJF: (a) SST Nov-SALLJ during NDJF, (b) SST Oct-SALLJ during NDJF, and (c) SST Sep-SALLJ during NDJF. Contours are plotted for the zero line (broken), and for $\pm 0.2,0.3$, and 0.4 . Statistical significance at $5 \%$ is shown in gray shaded areas.

the central equatorial Pacific feature a wakening of the SALLJ and a rainfall pattern that is associated with an intensified and poleward-shifted SACZ. This situation was more clearly observed during the 1997/98 El Niño and 1998/89 La Niña by Nieto Ferreira et al. (2003) and Zhou and Lau (2003).

In Mariscal Estigarribia, the cold season SALLJs do not exhibit a consistent signal due to El Niño, nor do we have any statistics derived from PACS-SONET that show greater or fewer SALLJs during the summertime of the 1998 El Niño or 1999 La Niña of SALLJ events detected at this site. The frequency of SALLJ events (Fig. 10b) shows larger numbers of jets during 196575 and 1985-95, approximately, with a very low number of SALLJ episodes during the 1950s. The intensity of the winds (mean of 0000-0600 UTC) shows a slight positive trend, with strong SALLJ episodes (even though less frequent) from 1995 to 2000.

The contrast between the increased number of SALLJ episodes detected during the warm season of the El Niño 1998 and the smaller number of SALLJ episodes during the 1999 La Niña cannot be generalized to all El Niño or La Niña events. Furthermore, this 1950-2000 climatology of SALLJ events is based on products generated by the NCEP-NCAR reanalyses, and without ob- servational evidence it is hard to validate SALLJ activity during other strong El Niño or La Niña years.

\section{Validation of SALLJ episodes derived from reanalyses}

SALLJ episodes were identified from the PACS-SONET pilot balloon profiles and from NCEP-NCAR reanalyses for grid boxes nearest to PACS-SONET sites. The focus is on Santa Cruz and Mariscal Estigarribia along the main axis of the SALLJ, for 1998-2000 where both the NCEP-NCAR reanalyses and pilot balloon observations were available. For Santa Cruz, Table 1 shows that for the summer of 1998 the number of observed low-level jets was larger than that during 1999. In January 1998, 10 LLJs were identified by the NCEPNCAR reanalyses while the PACS-SONET wind profiles showed 14 LLJ episodes. Both PACS-SONET and NCEP-NCAR reanalyses profiles agreed during six of those events. This agreement was also observed for one episode in February 1998 and two episodes in March 1998. In 1999 fewer SALLJ episodes were detected during the summer season, as is shown by both the reanalyses and PACS-SONET pilot balloons. The number of missing observations during the period January- 


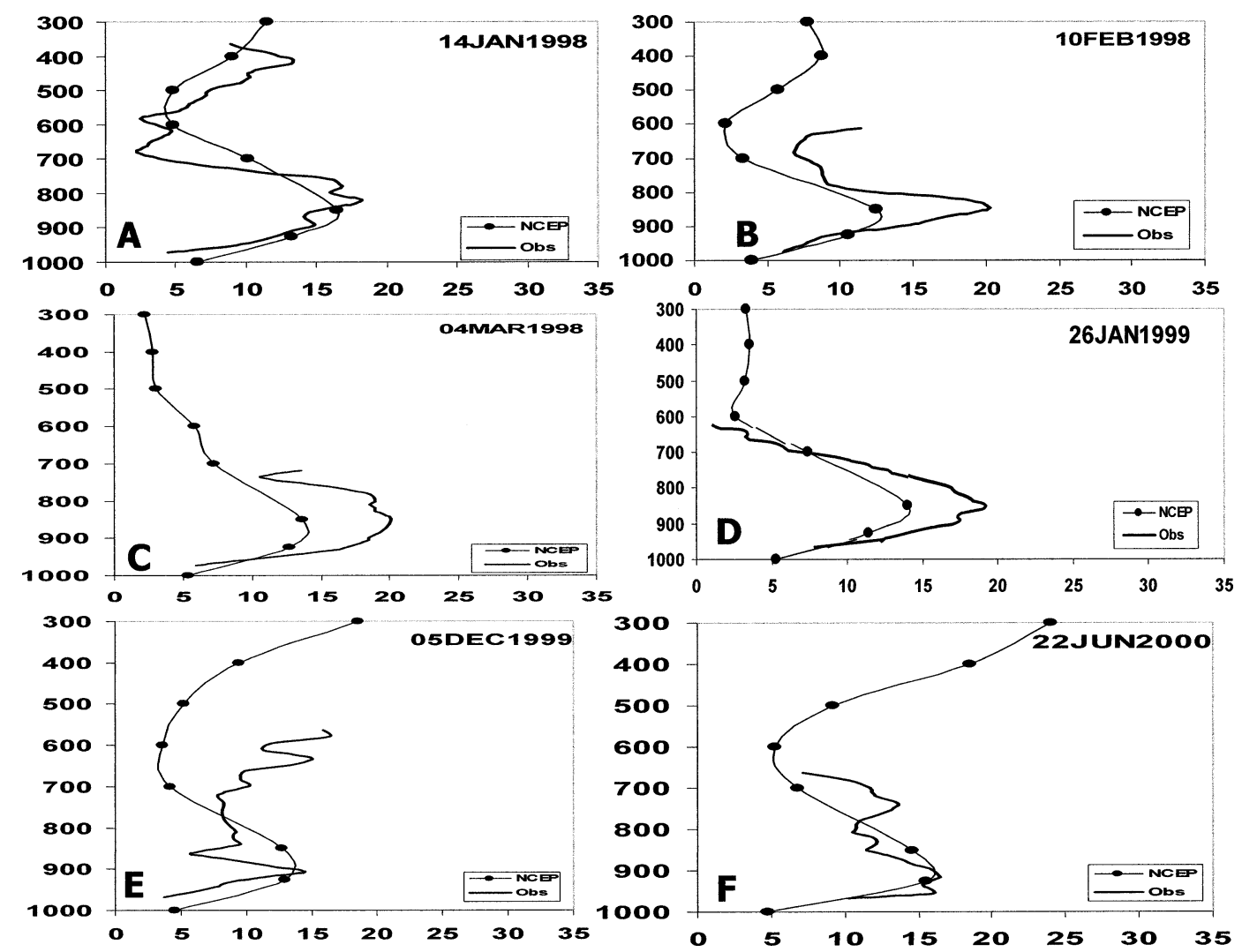

FIG. 13. Wind profiles derived from the NCEP-NCAR reanalyses (line with black circle) and from the PACS-SONET upper-air observations (solid lines) for days with the SALLJ detected in both reanalyses and observations in Santa Cruz during 1998-2000 for (a)-(f) Santa Cruz and (g)-(i) Mariscal Estigarribia. Refer to Tables 1 and 2 for more details.

March 1999 is almost the same as in 1998 (46 in 1999 and 45 in 1998). In November 2000, the Santa Cruz station became operational again, and even though we have $60 \%$ of missing observations, two SALLJ episodes were detected from the observations while the reanalyses do not show any episode at all.

In Mariscal Estigarribia, pilot balloon observations started at the end of 1999, and the percentage of missing data is significantly large, more than $50 \%$ of the month (Table 2). In December 1999, eight jet episodes were detected from the PACS-SONET profiles and only one of them was reproduced by the NCEP-NCAR reanalyses. In January 2000, with 20 days of observations, seven jet episodes were detected, while the NCEPNCAR reanalyses did not show any SALLJ at all. The numbers of jet episodes detected in both reanalyses and observations for 2000 were: one in June, one in September, one in October, and four in December.

An analysis of the wind profiles during some episodes of the SALLJ during 1998, 1999, and 2000 in both the reanalyses and observations (Figs. 13a-f) suggests that the reanalyses capture the position of the observed maximum low level winds $\sim 850 \mathrm{hPa}$, even though the reanalyses show a systematic underestimation especially in the lower and middle atmosphere for both Santa Cruz and Mariscal Estigarribia. There is a disagreement be- tween the observed and NCEP-NCAR reanalysis derived wind profiles, possibly due to errors in the data quality control. Figure $13 \mathrm{j}$ shows that even though the NCEP-NCAR reanalyses represent well the wind profiles, the observed maximum is almost twice the maximum wind derived from the reanalyses. The differences may be due to (a) the station data being compared with grid box data, (b) the PACS-SONET soundings showing higher vertical resolution while the reanalyses are available for the mandatory vertical levels, and (c) the reanalyses tending to smooth out what should be a sharp vertical structure of the real atmosphere, therefore not complying with Bonner criterion 1 and not depicting an SALLJ episode that otherwise could be detected if the reanalysis had higher vertical resolution. Since few or no upper-air observations east of the Andes in the SALLJ region have been assimilated into the model that produced the reanalyses, it is possible that the reanalyses in the SALLJ area better represent the modeled circulation.

\section{Discussion and conclusions}

An analysis of the 1950-2000 four times daily NCEP-NCAR reanalyses for the region east of the Andes has provided a detailed climatological description 


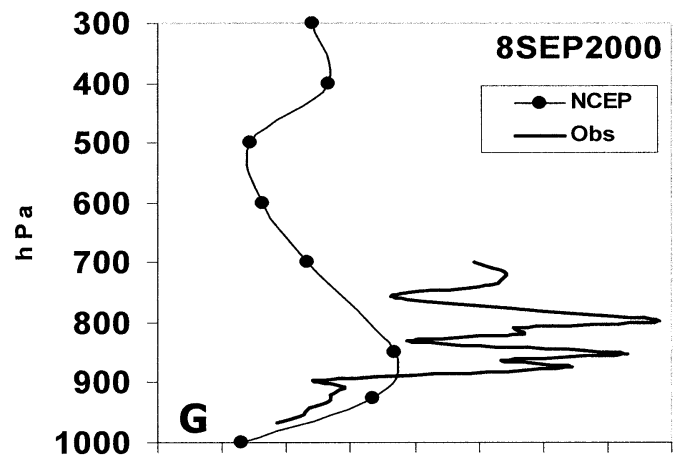

$\begin{array}{llllllllll}0 & 5 & 10 & 15 & 20 & 25 & 30 & 35 & 40\end{array}$

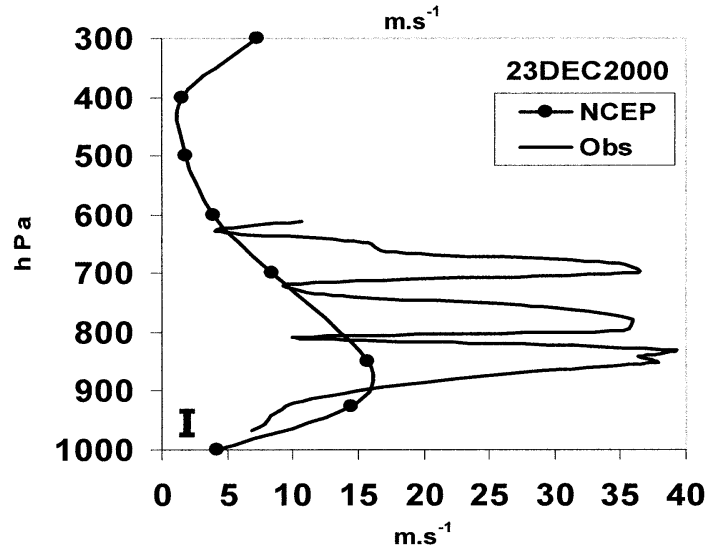

FIG. 13. (Continued)
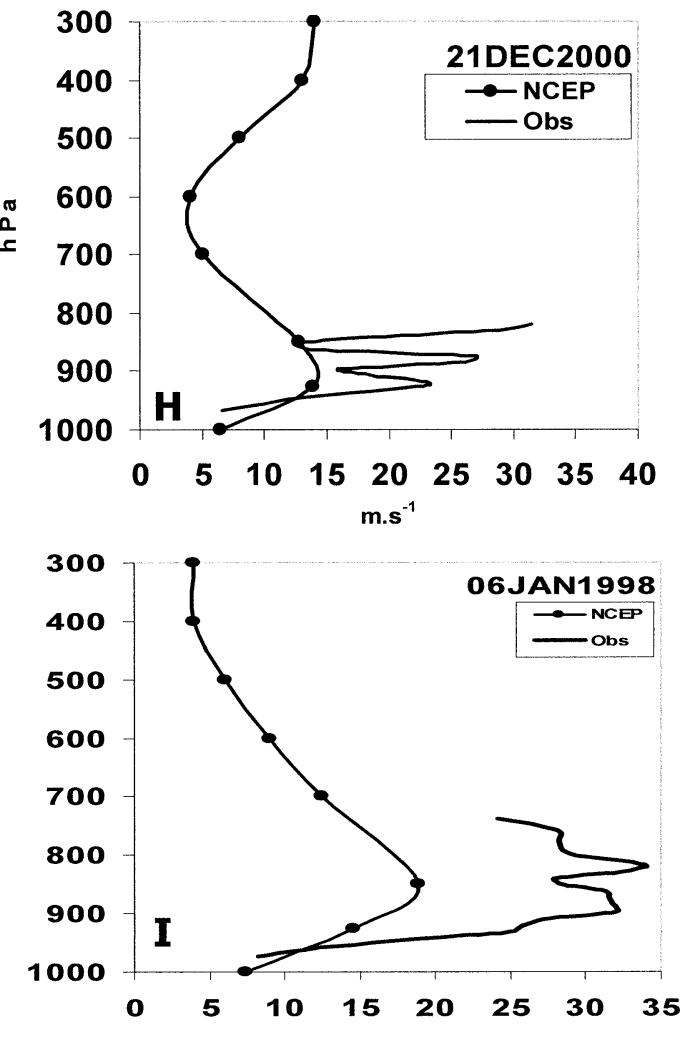

TABLE 1. SALLJ episodes in Santa Cruz as detected by the NCEP-NCAR reanalyses and the PACS-SONET pilot balloon observations. Bonner criterion 1 was applied to the wind profiles: $\mathrm{X}=$ SALLJ detected by Bonner criterion 1; black = none or incomplete observation where Bonner criterion 1 cannot be applied; white = observations available but do not meet Bonner criterion 1 to qualify as an SALLJ.

\begin{tabular}{|c|c|c|c|c|c|c|c|c|c|c|c|c|c|c|c|c|c|c|c|c|c|c|c|c|c|c|c|c|c|c|c|}
\hline Day in Jan 1998 & 1 & 2 & 3 & 4 & 5 & 6 & 7 & 8 & 9 & 10 & 11 & 12 & 13 & 14 & 15 & 16 & 17 & 18 & 19 & 20 & 21 & 22 & 23 & 24 & 25 & 26 & 27 & 28 & 29 & 30 & 31 \\
\hline PACS SONET & & & & & & $x$ & & & & & $\mathrm{x}$ & & & $x$ & $x$ & $\mathrm{X}$ & $\mathrm{x}$ & & & & $\mathrm{X}$ & $x$ & $\mathrm{x}$ & $\mathrm{x}$ & & $x$ & $x$ & & $\mathrm{x}$ & $\mathrm{x}$ & \\
\hline NCEP-NCAR & $x$ & & & & & $x$ & & & $x$ & & $x$ & $x$ & & $x$ & & & $x$ & & & & & & & & & $x$ & $x$ & $\mathrm{X}$ & & & \\
\hline Day in Feb 1998 & 1 & 2 & 3 & 4 & 5 & 6 & 7 & 8 & 9 & 10 & 11 & 12 & 13 & 14 & 15 & 16 & 17 & 18 & 19 & 20 & 21 & 22 & 23 & 24 & 25 & 26 & 27 & 28 & & & \\
\hline PACS SONET & & & & $x$ & & & $x$ & & & $x$ & & & & & & & & & & & & $x$ & & & & & & & & & \\
\hline NCEP-NCAR & & $\mathrm{X}$ & & & & & & & $x$ & $\mathrm{x}$ & & & & & & & $x$ & $\mathrm{x}$ & & & & & & & $x$ & $x$ & & & & & \\
\hline Day in Mar 1998 & 1 & 2 & 3 & 4 & 5 & 6 & 7 & 8 & 9 & 10 & 11 & 12 & 13 & 14 & 15 & 16 & 17 & 18 & 19 & 20 & 21 & 22 & 23 & 24 & 25 & 26 & 27 & 28 & 29 & 30 & 31 \\
\hline PACS SONET & & & & $\mathrm{x}$ & & $x$ & & $x$ & $x$ & $x$ & & & & & & & & & & & & & & & & & & & & & \\
\hline NCEP-NCAR & & & & $x$ & & $x$ & & & & & & & & & & & & & & & & $x$ & & $\mathrm{x}$ & & & & & & & \\
\hline Day in Jan 1999 & 1 & 2 & 3 & 4 & 5 & 6 & 7 & 8 & 9 & 10 & 11 & 12 & 13 & 14 & 15 & 16 & 17 & 18 & 19 & 20 & 21 & 22 & 23 & 24 & 25 & 26 & 27 & 28 & 29 & 30 & 31 \\
\hline PACS SONET & & & & & & & & & & & & & & & & & & & & & & & & & & & & $x$ & & & \\
\hline NCEP-NCAR & & & & & & & & & & & & & & & & & & $\mathrm{X}$ & & & & & & & & & & $\mathrm{X}$ & & & $x$ \\
\hline Day in Feb 1999 & 1 & 2 & 3 & 4 & 5 & 6 & 7 & 8 & 9 & 10 & 11 & 12 & 13 & 14 & 15 & 16 & 17 & 18 & 19 & 20 & 21 & 22 & 23 & 24 & 25 & 26 & 27 & 28 & & & \\
\hline PACS SONET & & & & & & & & & & & & & & & & & & & & & & & $x$ & & & & & & & & \\
\hline NCEP-NCAR & & $\mathrm{X}$ & & & & & & & & & & & $\mathrm{X}$ & & & & & & & & & & & & & & & & & & \\
\hline Day in Mar 1999 & 1 & 2 & 3 & 4 & 5 & 6 & 7 & 8 & 9 & 10 & 11 & 12 & 13 & 14 & 15 & 16 & 17 & 18 & 19 & 20 & 21 & 22 & 23 & 24 & 25 & 26 & 27 & 28 & 29 & 30 & 31 \\
\hline PACS SONET & & & & & & & & & & & & & & $x$ & & & & & & & & & & & & & & $x$ & & & \\
\hline NCEP-NCAR & & & & & & & & & & & & & & & & & & & & & & & & & & & & & & & \\
\hline Day in Apr 1999 & 1 & 2 & 3 & 4 & 5 & 6 & 7 & 8 & 9 & 10 & 11 & 12 & 13 & 14 & 15 & 16 & 17 & 18 & 19 & 20 & 21 & 22 & 23 & 24 & 25 & 26 & 27 & 28 & 29 & 30 & \\
\hline PACS SONET & & & & & & & & & & & & & & & $x$ & $\mathrm{x}$ & & & & & & & & & & & & & & & \\
\hline NCEP-NCAR & & & & & & & & & & & & & & & & & & & & & & & & & & & & & & & \\
\hline Day in Nov 2000 & 1 & 2 & 3 & 4 & 5 & 6 & 7 & 8 & 9 & 10 & 11 & 12 & 13 & 14 & 15 & 16 & 17 & 18 & 19 & 20 & 21 & 22 & 23 & 24 & 25 & 26 & 27 & 28 & 29 & 30 & \\
\hline PACS SONET & & & & $x$ & & & & & & & & & & & & & & & & & & & $\mathrm{X}$ & & & & & & & & \\
\hline NCEP-NCAR & & & & & & & & & & & & & & & & & & & & & & & & & & & & & & & \\
\hline
\end{tabular}


TABLE 2. Same as Table 1, except for SALLJ episodes in Mariscal Estigarribia.

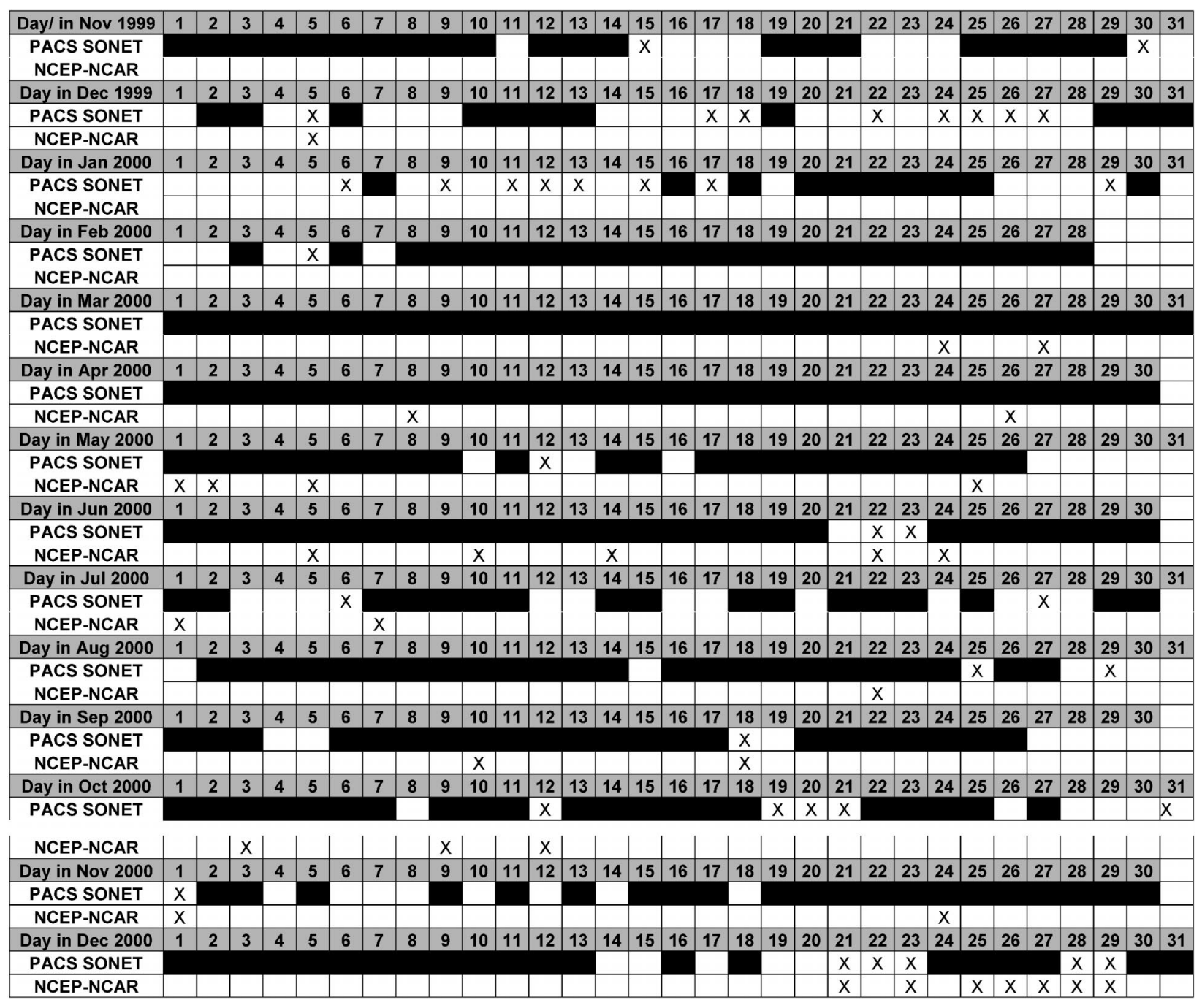

of the SALLJ, regarding its time and space characteristics. Patterns are stronger when the SALLJ condition is satisfied both over Santa Cruz and over Mariscal Estigarribia. The low-level circulation associated with the composites of SALLJs during summer shows the intensification of the typical mean summertime circulation features, specifically the low-level flow east of the Andes and the enhanced meridional moisture transport coming from tropical South America, which is stronger than that of the mean summer season. The upper-level circulation shows a wave train emanating from the western Pacific near Australia-New Zealand, propagating toward South America, and moving to the northeast after reaching the southern tip of the continent. The intensification of the SALLJ over Santa Cruz follows the establishment of an upper-level ridge over southern Brazil and a trough over most of Argentina, with the pattern reaching somewhat larger amplitudes for SALLJs detected in northern Paraguay.

SALLJ episodes are detected all year long, with $75 \%$ of the cases detected during NDJF along the axis of the SALLJ near Santa Cruz, and 25\% occurring predominantly during spring and autumn. In Mariscal Estigarribia, located near the exit region of the SALLJ, $45 \%$ of the cases were detected during MJJA and 29\% during November-December. While virtually no LLJs are detected in the U.S. Great Plains during the cold season, SALLJ episodes can be detected during winter too, even though the moisture content of the air masses is lower than during the warm season. During the warm season, the height of the core of the jet east of the Andes $(\sim 12$ $\mathrm{m} \mathrm{s}^{-1}$ ) is $\sim 850 \mathrm{hPa}$ at $62^{\circ} \mathrm{W}$, with a shallow and relatively weaker $\left(\sim 4 \mathrm{~m} \mathrm{~s}^{-1}\right)$ second jet near the Brazilian Planalto $\left(\sim 40^{\circ} \mathrm{W}\right)$. Strong SALLJ events were identified 
as those occurring both in Santa Cruz and Mariscal Estigarribia, and during the warm season. More frequent wintertime SALLJs are related to the intensity and position of the subtropical Atlantic anticyclone. In this case, the source of moisture is the tropical and subtropical Atlantic, during the summertime SALLJ. The most important source is the northeast winds deflected to the southwest, with enriched moisture content provided by the Amazon basin, with a less pronounced secondary moisture supply coming from the subtropical Atlantic Ocean.

At interannual time scales, even though there have been more frequent and stronger SALLJ episodes identified during the $1998 \mathrm{El}$ Niño as compared to the 1999 La Niña, there is no strong statistical evidence that suggests that more SALLJ episodes are detected during El Niño years or less strong or frequent SALLJs during La Niña years. Of course, the low percentage of the variance of the SALLJ explained by tropical Pacific SST anomalies indicates that other factors make important contributions to this variability, factors such as the assimilation of satellite data or some other nonmeteorological causes. Given the uncertainties in the ability of the NCEP-NCAR reanalyses in studying interannual variability of the SALLJ due to changes in assimilation techniques and the introduction of satellite data during the late 1970s, we analyzed the circulation features and the number of SALLJ occurrences in Santa Cruz during 1950-2000 and 1979-2000 and we have not noticed any significant difference in the low-level circulation features or the frequency of SALLJ cases that could be attributed to changes in the data ingested into the reanalyses.

The reanalyses for the SALLJ region east of the Andes are produced by model output in a region where few observations are assimilated by the model. Thus, it is possible that the reanalyses show only the circulation features generated by the model. In any case, we use the wind at station level from PACS-SONET compared with the wind from a $250 \mathrm{~km} \times 250 \mathrm{~km}$ grid box to explain this underestimation. It should also be pointed out that the observations provided by PACS-SONET exhibit many discontinuities. This fact suggests that results from this dataset should be interpreted cautiously.

While the reanalyses show some success in depicting the structure and characteristics of the SALLJ as well as its variability in time, they do show some limitations in reproducing the diurnal cycle or the interannual variability. This is due in part to the lack of continuous upper-air observations in time and space that are assimilated by the NCEP-NCAR model to generate the reanalyses, and it is necessary to validate these results with a larger and better observational network. The Bonner criterion 1 applied to either upper-air stations or to the grid box closest to the stations using the reanalyses products helps to identify an SALLJ by taking into account the low-level wind speeds and wind profiles. However, this criterion does not specify the character- istics of the air mass, thus allowing SALLJs in summer and winter and from tropical and subtropical sources. The discrepancy between the diurnal cycle derived from the surface-upper-air observations and the NCEPNCAR reanalyses indicates the need for more observations, and a more accurate evaluation of the diurnal cycle will be accomplished through a dense network of observations at least four to six times per day. This has been one of the major objectives of the South American Low Level Jet Experiment (SALLJEX) that took place during the austral summer of 2002/03, as part of the Variability of South American Monsoon Systems (VAMOS) project.

Acknowledgments. We wish to thank the NOAA Office of Global Programs for supporting the PACS-SONET observation program, one component of which was operating the Santa Cruz, Bolivia, sounding site. Additional thanks go to Jan and Julia Paegle, V. Kousky, M. Seluchi, M. Silva Dias, I. Cavalcanti, P. Silva Dias, M. Douglas, others from the University of Utah, CPTEC/INPE, NCEP, the University of Buenos Aires, and the University of São Paulo. This study was funded by the Inter American Institute for Global Change (IAI; Grant IAI-CRN 055 PROSUR) and an FAPESP Grant (01/13816-1).

\section{REFERENCES}

Anderson, C. J., and R. Arrit, 2001: Representation of summertime low-level jets in the central United States by NCEP-NCAR reanalyses. J. Climate, 14, 234-247.

Berbery, E. H., and E. A. Collini, 2000: Springtime precipitation and water vapor flux convergence over southeastern South America. Mon. Wea. Rev., 128, 1328-1346.

__ , and V. Barros, 2002: The hydrological cycle of the La Plata basin in South America. J. Hydrometeor., 3, 630-645.

Berri, G. J., and B. Inzunza, 1993: The effect of the low-level jet on the poleward water vapor transport in the central region of South America. Atmos. Environ., 27A, 335-341.

Blackadar, A., 1957: Boundary layer wind maxima and their significance for the growth of nocturnal inversions. Bull. Amer. Meteor. Soc., 38, 283-290.

Bonner, W. D., 1968: Climatology of the low level jet. Mon. Wea. Rev., 96, 833-850.

Cazes-Boezio, G. H., A. W. Robertson, and C. R. Mechoso, 2003: Seasonal dependence of ENSO teleconnections over South America and relations with precipitation in Uruguay. J. Climate, 16, 1159-1176.

Douglas, M. W., M. Nicolini, and C. Saulo, 1998: Observational evidences of a low level jet east of the Andes during JanuaryMarch 1998. Meteorologica, 23, 63-72.

,-- , and -1999 : The low-level jet at Santa Cruz, Bolivia during January-March 1998, pilot balloon observations and model comparisons. Preprints, 10th Symp. on Global Change Studies, Dallas, TX, Amer. Meteor. Soc., 223-226.

—_, M. Peña, and R. Villarpando, 2000: Special observations of the low level flow over eastern Bolivia during the 1999 atmospheric mesoscale campaign. Preprints, Sixth Int. Conf. on Southern Hemisphere Meteorology and Oceanography, Santiago, Chile, Amer. Meteor. Soc., 157-158.

Garreaud, R., and J. M. Wallace, 1998: Summertime incursions of midlatitude air into subtropical and tropical South America. Mon. Wea Rev., 126, 2713-1733. 
Herdies, D. L., A. Da Silva, M. A. Silva Dias, and R. Nieto-Ferreira, 2002: Moisture budget of the bimodal pattern of the summer circulation over South America. J. Geophys. Res., 107, 8075, doi:10.1029/2001JD000997.

Inzunza, B. J., and G. J. Berri, 1980: Campo de Movimiento y transporte de humedad asociado en la baja tropos fera en el norte de Argentina. Meteorologica, 17, 17-25.

Kalnay, E., and Coauthors, 1996: The NCEP/NCAR 40-Year Reanalyses Project. Bull. Amer. Meteor. Soc., 77, 437-471.

Labraga, J. C., O. Frumento, and M. Lopez, 2000: The atmospheric water vapor in South America and the tropospheric circulation. J. Climate, 13, 1899-1915.

Lau, K.-M., and J. Zhou, 2003: Anomalies of the South American summer monsoon associated with the 1977-99 El Niño Southern Oscillation. Int. J. Climatol., 23, 529-529.

Li, L., and H. Le Treut, 1999: Transient behavior of the meridional moisture transport across South America and its relation to atmospheric circulation patterns. Geophys. Res. Lett., 26, 14091412.

Liebmann, B., G. Kiladis, J. Marengo, T. Ambrizzi, and J. Glick, 1999: Submonthly convective variability over South America and the South Atlantic convergence zone. J. Climate, 12, $1877-$ 1891.

— — - C. Vera, C. Saulo, and L. Carvalho, 2004: Subseasonal variations of rainfall in South America in the vicinity of the lowlevel jet east of the Andes and comparison to those in the South Atlantic convergence zone. J. Climate, in press.

Marengo, J. A., and W. Soares, 2002: Episodio de Jatos de baixos níveis durante 13 a 19 de abril de 1999. Rev. Bras. Meteor., 17, 35-52.

_ low-level jet east of the Andes during the 1999 LBA-TRMM and LBA-WET AMC campaign. J. Geophys. Res., 107, 8079, doi:10.1029/2001JD001188.

Means, L., 1952: On thunderstorm forecasting in the central United States. Mon Wea Rev., 80, 165-189.

— 1954: A study of the mean southerly wind maximum in low levels associated with a period of summer precipitation in the middle west. Bull. Amer. Meteor. Soc., 35, 116-170.

Misra, V., P. Dirmeyer, B. Kirtman, H. Huang, and M. Kanamitsu, 2000: Regional simulation of interannual variability over South America. COLA Tech. Rep. 85, 42 pp.

Mo, K. C., and J. N. Paegle, 2001: The Pacific-South American modes and their downstream effects. Int. J. Climatol., 21, 12111229.

Nicolini, M., C. Saulo, J. C. Torres, and P. Salio, 2002: Enhanced precipitation over southeastern South America related to lowlevel jet events during austral warm season. Meteorologica, 27, 59-70.

Nieto Ferreira, R., T Rickenbach, D. Herdies, and L. Carvalho, 2003:
Variability of South American convective cloud systems and tropospheric circulation during January-March 1998 and 1999. Mon. Wea. Rev., 131, 961-973.

Nogués-Paegle, J., and K.-C. Mo, 1997: Alternating wet and dry conditions over South America during summer. Mon. Wea. Rev., 125, 279-291.

_ _ and Coauthors, 2002: Progress in pan American CLIVAR research: Understanding the South American monsoon. Meteorologica, 27, 3-32.

Paegle, J. N., and Coauthors, 2001: American low level jets-A scientific prospectus and implementation plan. International CLIVAR Project office, Southampton, United Kingdom, 120 pp. [Available online at http://www.clivar.org/publications/wg-reports/ vamos/pdf_files/alls.pdf.]

Rao, V. B., I. F. Cavalcanti, and K. Hada, 1996: Annual variation of rainfall over Brazil and water vapor characteristics over South America. J. Geophys. Res., 101, 26 539-26 551.

Salio, P., M. Nicolini, and C. Saulo, 2002: Chaco low-level jet events characterization during the austral summer season. J. Geophys. Res., 107, 4816, doi:10.1029/2001JD001315.

Saulo, C., M. Nicolini, and S. C. Chou, 2000: Model characterization of the South American low-level flow during the 1997-98 spring-summer season. Climate Dyn., 16, 867-881.

Seluchi, M., and J. Marengo, 2000: Tropical-midlatitude exchange of air masses during summer and winter in South America: Climatic aspects and extreme events. Int. J. Climatol., 20, $1167-$ 1190.

Silva Dias, M., and Coauthors, 2002: Cloud and rain processes in a biosphere-atmosphere interaction context in the Amazon basin. J. Geophys. Res., 107, 8072, doi:10.1029/2001JD000335.

Stensrud, D., 1996: Importance of low-level jets to climate: A review. J. Climate, 9, 1698-1711.

Sugahara, S., R. P. Rocha, and M. L. Rodrigues, 1994: Condições atmosféricas de grande escala associadas a jato de baixos níveis na América do Sul. Proc. Eighth Brazilian Congress of Meteorology, Vol. 2, Belo Horizonte, Minas Gerais, Brazil, Brazilian Meteorological Society, 573-577.

Vera, C., S. P. K. Vigliarolo, and E. H. Berbery, 2002: Cold season synoptic scale waves over subtropical South America. Mon. Wea. Rev., 130, 684-699.

Vernekar, A., B. Kirtman, and M. Fennessy, 2003: Low-level jets and their effects on the South American summer climate as simulated by the NCEP Eta Model. J. Climate, 16, 297-311.

Virji, H., 1981: A preliminary study of summertime tropospheric circulation patterns over South America estimated from cloud winds. Mon. Wea. Rev., 109, 596-610.

von Storch, H., and F. Zwiers, 1999: Statistical Analysis in Climate Research. Cambridge University Press, 455 pp.

Whiteman, C., X. Bian, and S. Zhong, 1997: Low-level jet climatology from enhanced rawinsonde observations at a site in the southern Great Plains. J. Appl. Meteor., 36, 1363-1375. 